School of Finance

University of St.Gallen

COMMON RISK FACTORS OF INFRASTRUCTURE FIRMS

SEMIR BEN AMMAR

MARTIN ELING

WORKING PAPERS ON FinANCE No. 2013/7

INSTITUT FÜR VERSICHERUNGSWIRTSCHAFT (I.VW - HSG)

MAY 2013 


\title{
Common Risk Factors of Infrastructure Firms
}

\author{
Semir Ben Ammar*† $\quad$ Martin Eling*
}

This version: $05 / 07 / 2013$

\begin{abstract}
The risk of infrastructure firms is driven by unique factors that cannot be well described by standard asset class factor models. We thus create a seven-factor model based on infrastructure-specific risk exposure, i.e., market risk, cash flow volatility, leverage, investment growth, term risk, default risk, and regulatory risk. We empirically test our model on a large dataset of U.S. infrastructure stocks in different subsectors (utility, telecommunication, and transportation) and over a long period of time (1980 to 2011). The new factor model is able to capture the variation of infrastructure returns better than the Fama/French three-factor or the Carhart four-factor models. Thus, our model helps to better determine the cost of capital of infrastructure firms, something that is increasingly relevant in light of the growing need for privately financed infrastructure projects.
\end{abstract}

Keywords: Infrastructure, Asset class, Factor model, Fama/French factors, Leverage, Cash flow volatility, Investment factor

JEL classification: G11; G12; G19; O18

${ }^{*}$ The authors are with the School of Finance, University of St. Gallen, Kirchlistr. 2, CH-9010 St. Gallen.

†Corresponding author. Tel.: +41 71224 7994; Fax: +41 71243 4040. E-mail address: semir.benammar@unisg.ch 


\section{Introduction}

The aim of this paper is to derive an asset class factor model for infrastructure investments that explains the specific characteristics of these investments. The study is motivated by the claims of investment advisors and many trade articles that infrastructure investments have a number of unique characteristics, such as uncorrelated returns with major asset classes, stable cash flows because of government regulation, and inflation protection (see Newell and Peng (2008); Finkenzeller, Dechant, and Schäfers (2010); Bird, Liem, and Thorp (2012)). For these reasons, institutional investors increasingly seek infrastructure investments as an alternative asset class promising sustainable returns at relatively low risk.

There is very little academic work on infrastructure investments and most of the studies that do exist use only infrastructure indices and a limited period of investigation. Newell and Peng (2008) analyze U.S. infrastructure indices with respect to risk-adjusted performance and portfolio diversification and show that listed infrastructure improved portfolio performance during the period 2003 to 2006, but strongly underperformed other asset classes during 2000 and 2003. Looking at Australian and U.S. infrastructure indices, Finkenzeller, Dechant, and Schäfers (2010) and Dechant and Finkenzeller (2012) document the asset allocation benefits of infrastructure both in a mean-variance and a mean-downside risk framework. Bitsch, Buchner, and Kaserer (2010) compare the infrastructure deals of private equity funds with noninfrastructure deals and find higher performance and lower default rates for infrastructure investments, but no evidence of more stable cash flows. To date, Bird, Liem, and Thorp (2012) is the only study to extent the traditional Fama/French three-factor for infrastructure investments. They show that infrastructure offers a partial inflation hedge, but they reject the hypothesis that infrastructure has defensive characteristics in the sense that infrastructure firms perform well during economic downturns.

This paper contributes to the empirical literature on infrastructure by developing an asset class factor model for infrastructure investments. ${ }^{1}$ Based on the extant literature, we identify six factors in addition to the market beta that are characteristic for infrastructure firms in terms of risk and return: cash flow volatility, leverage, an investment growth factor, a term premium, a default premium, and a regulatory premium. We use these factors to develop a seven-factor model and an augmented 10-factor model that is built on Carhart (1997). We empirically test the new models on a large dataset of U.S. infrastructure

\footnotetext{
${ }^{1}$ Bird, Liem, and Thorp (2012) restrict their analysis to the inflation hedge and downside protection characteristics, thereby controlling for conditional heteroscedasticity (using GARCH models) and the impact of regulatory power through simulations of a covered call strategy. We expand their model by factors related to cash flow volatility, leverage effects, investment growth, default risk, term premium, and the consideration of a very long time horizon. Furthermore, we look at individual infrastructure returns; Bird, Liem, and Thorp (2012) consider indices.
} 
companies. The empirical focus on U.S. firms is advantageous for three reasons. (1) Most of the existing infrastructure papers consider markets outside the United States even though there is a great need for infrastructure investment in the United States. ${ }^{2}$ (2) A long time horizon can be investigated, which allows us to consider different subperiods. (3) Analyzing individual shares of infrastructure firms instead of indices allows us to sort portfolios by size and book-to-market ratio to control for stock anomalies and, thus, enhances the validity of the infrastructure models.

This paper extends the findings of Bird, Liem, and Thorp (2012) by going beyond the aspects of inflation and downside protection and creates a detailed asset class factor model for infrastructure stocks that takes into account the relation between stock performance and cash flow volatility, large-scale up-front investments, high financial leverage, interest rate sensitivity, and regulatory impact. Our paper contributes to the emerging body of literature on the risk-return characteristics of infrastructure in several ways. First, we help explain the return variation in infrastructure stocks to improve the measurement of cost of capital and performance for such companies. We show that an infrastructure seven-factor model based only on the infrastructure-specific characteristics is superior in explaining the cross-section of infrastructure returns compared to the Fama/French three-factor or the Carhart four-factor models. Second, we shed some light on the mixed results in the literature as to whether infrastructure generates stable cash flows and tackle the heretofore unaddressed issue of infrastructure being sensitive to interest rate changes. Finally, we show that financial leverage contains more information about the variation in infrastructure returns than does the high minus low book-to-market factor (HML).

Finding the common risk factors among infrastructure companies is important in understanding the pricing process of such firms. This is true for both investors and for public policymakers, who, in light of increasing privatization in the United States, need to know the fair rates of return so as to prevent monopolistic exploitation (Kessides (2004); Newbery (2002)). Our results allow better understanding of the risk and return drivers of infrastructure investments. We show that investors value cash flow stability with a premium and find that infrastructure firms are sensitive to interest rate changes with respect to

\footnotetext{
${ }^{2}$ Although for several decades in the United States, capital has been allocated to alternative investments such as private equity or hedge funds, investors there have only recently begun to pay attention to infrastructure as an investment opportunity. While other markets, such as the United Kingdom, Canada, and, especially, Australia, discovered infrastructure as an alternative field of investment in the early 1990s, the United States "do[es] not have a strong history of infrastructure privatization" (Newell and Peng (2008)). However, the current debt crisis in the United States implies a strict fiscal policy that will continue to affect public spending for infrastructure projects, while continuous urban development and growth in the country will demand intensive investment in infrastructure. Due to this increasing importance of infrastructure in the United States from both a governmental and investor point of view, the empirical part of this study focuses on the U.S. infrastructure sector.
} 
the term and default premium. Furthermore, we show that only companies with low book-to-market ratios tend to invest in their asset base, which is positively valued with a risk premium.

The following section reviews the infrastructure literature and derives an asset class factor model for infrastructure stocks. Section 3 discusses the data and how the factors are constructed. Section 4 presents the empirical results, including robustness tests. Section 5 concludes.

\section{Model Development and Hypotheses}

Finkenzeller, Dechant, and Schäfers (2010) point out that infrastructure, despite having some characteristics in common with real estate, cannot be classified as such due to the monopolistic, less transparent structures, higher regulatory constraints, and higher investment necessary for the realization of infrastructure projects compared to real estate.

Thus, the goal of this paper is to derive an asset class factor model for infrastructure based on the specific characteristics infrastructure companies are believed to have. More specifically, we want to determine which characteristics (i.e., mimicking portfolios) offer the highest explanatory power for the return variation of infrastructure firms. One of the major challenges in constructing such a model is that - depending on the definition - "infrastructure" covers a wide array of activity. For example, companies operating pipelines might be affected by oil prices, but the returns of telecommunication businesses are not. Common to these companies are operational networks (Newbery (2002)) characterized by low risk, stable cash flows, high debt-to-equity ratios, a monopolistic structure, downside protection, and large-scale investments. We replicate these common characteristics to explain the cross-section of the return profiles. We also test whether the infrastructure sector is homogenous or heterogeneous by separately analyzing different subsectors (utility and non-utility firms) and analyze downside and inflation protection in more detail.

Table 1 summarizes the infrastructure characteristics analyzed in previous studies. Rothballer and Kaserer (2012) observe low market beta values and conclude that infrastructure is less risky than the overall market. Results about inflation are ambiguous, but it seems that no general inflation hedge is provided by infrastructure investments. Cash flow volatility is analyzed by Bitsch (2012), who finds more stable cash flow for unlisted infrastructure deals but cannot confirm a premium for such stability. Uncorrelated returns with traditional asset classes are confirmed for Australia by Finkenzeller, Dechant, 
and Schäfers (2010), a result that goes hand in hand with the low beta characteristic. Bird, Liem, and Thorp (2012) cannot confirm any downside protection from infrastructure investments. The interest rate sensitivity of infrastructure assets that might arise from the long-term horizon of future cash flows has not yet been analyzed.

Table 1: Characteristics of infrastructure investments and results from existing literature

\begin{tabular}{|c|c|c|}
\hline Characteristic & Measured by & Result in existing literature \\
\hline Low risk & RM-Rf & $\begin{array}{l}\text { Rothballer and Kaserer (2012): } \\
\text { market risk is lower compared to } \\
\text { other equities. }\end{array}$ \\
\hline Inflation hedge & $\begin{array}{l}\text { Consumer Price Index (CPI), Trea- } \\
\text { sury Inflation Protected Securities } \\
\text { (TIPS) }\end{array}$ & $\begin{array}{l}\text { Rödel and Rothballer (2012): hedge } \\
\text { appears to be more wishful thinking } \\
\text { than empirical fact; Bird, Liem, and } \\
\text { Thorp (2012): support for utility } \\
\text { sector to hedge against inflation but } \\
\text { not infrastucture as a whole. }\end{array}$ \\
\hline Stable cash flows & Volatility of cash flows & $\begin{array}{l}\text { Bitsch (2012): infrastructure pro- } \\
\text { vides more stable cash flows than } \\
\text { non-infrastructure investments, but } \\
\text { investors' value cash flow volatility } \\
\text { at a premium. }\end{array}$ \\
\hline Uncorrelated returns & $\begin{array}{l}\text { Comparison with returns of stocks, } \\
\text { bonds, real estate }\end{array}$ & $\begin{array}{l}\text { Finkenzeller, Dechant, and Schäfers } \\
(2010) \text { : low correlations with tradi- } \\
\text { tional asset classes in Australia. }\end{array}$ \\
\hline Downside protection & $\begin{array}{l}\text { Market timing (i.e., squared market } \\
\text { factor) }\end{array}$ & $\begin{array}{l}\text { Bird, Liem, and Thorp (2012): no } \\
\text { downside protection of infrastruc- } \\
\text { ture investments. Dechant and } \\
\text { Finkenzeller }(2012) \text { : direct infras- } \\
\text { tructure investments reduce down- } \\
\text { side risk in portfolios. }\end{array}$ \\
\hline
\end{tabular}

The literature proposes two approaches for the construction of asset class factor models. The first is to consider macroeconomic factors; the second is to construct return portfolios based on firm-specific characteristics that reflect underlying risks (Campbell, Lo, and MacKinlay (1997)). Including both firmspecific and macroeconomic factors in the form of excess returns as in Fama and French (1993), we create dynamic portfolios that capture the infrastructure-specific relation between risk and return. Using mimicking portfolios measured as excess returns allow us to reveal pricing errors through a significant intercept in the time-series regression model, i.e., the alpha not being equal to zero for all test assets (Gibbons, Ross, and Shanken (1989)).

We consider a combination of common equity factors (i.e., Fama/French factors and momentum) and additional risk factors to explain the return variation of infrastructure stocks. We therefore augment the Carhart four-factor model with a cash flow volatility factor, an investment factor (Chen, Novy-Marx, 
and Zhang (2011)), and a leverage factor, as well as with a term, default, and regulatory risk premium. For comparison, we also present the capital asset pricing model (CAPM), the Fama/French three-factor model, and the Carhart four-factor model. The CAPM (Sharpe (1964); Lintner (1965); Mossin (1966)) uses the market excess return $\left(R_{M, t}-R_{f, t}\right)$ to explain stock returns:

$$
R_{i, t}-R_{f, t}=\alpha_{i}+\beta_{i, M}\left(R_{M, t}-R_{f, t}\right)+\epsilon_{i, t}
$$

However, the CAPM cannot explain anomalies such as the size effect or the performance differences between value and growth stocks. Fama and French $(1992,1993)$ developed a model to account for these empirical facts:

$$
R_{i, t}-R_{f, t}=\alpha_{i}+\beta_{i, M}\left(R_{M, t}-R_{f, t}\right)+\beta_{i, S M B} S M B_{t}+\beta_{i, H M L} H M L_{t}+\epsilon_{i, t} .
$$

The Fama/French three-factor model adds a zero investment portfolio to the pricing equation that goes long in stocks with small market capitalization and short in stocks with large market capitalization (SMB). The other factor is constructed as a zero investment portfolio going long in value stocks and short in growth stocks (HML). Though this model is able to explain much of the variation in returns, it does not capture the entire cross-sectional variation of stock returns (Fama and French (1993)).

Carhart (1997) extended this model by a momentum factor based on previous findings by Jegadeesh and Titman (1993) that past year winners outperform past year losers:

$$
R_{i, t}-R_{f, t}=\alpha_{i}+\beta_{i, M}\left(R_{M, t}-R_{f, t}\right)+\beta_{i, S M B} S M B_{t}+\beta_{i, H M L} H M L_{t}+\beta_{i, M O M} M O M_{t}+\epsilon_{i, t} .
$$

Given that our analysis deals with a specific industry, we would expect that these models can capture some of the return variation of infrastructure firms. However, the additional characteristics relevant for the pricing of infrastructure stocks will require an augmented CAPM, Fama/French three-factor, or Carhart four-factor model as, e.g., suggested by Mohanty and Nandha (2011) for U.S. oil and gas stocks or by Sadorsky (2001) for Canadian oil and gas stocks.

Bird, Liem, and Thorp (2012) are the first to develop an augmented factor model for infrastructure investments. In fact, they propose two separate models. The first model augments the Fama/French three-factor model with the yield of Treasury Inflation Protected Securities (TIPS) minus the risk-free 
rate. The second model includes a market timing factor that accounts for the defensive characteristics of infrastructure investments. Motivated by Treynor and Mazuy (1966), Bird, Liem, and Thorp (2012) replicate market timing by the squared market excess return, assuming that the defensive investment characteristic of infrastructure is able reduce the decline in infrastructure asset prices during economic downturns. Both models are corrected for conditional heteroscedasticity and non-linearities in the error term using the GARCH approach. Furthermore, they implement a covered call strategy to identify a regulatory risk premium for both the U.S. and Australian stock markets. The model is empirically tested for sub-indices of the UBS Global Infrastructure and Utilities Index starting between 1990 and 1998 and ending in December 2011.

Extending the Fama/French three-factor or the Carhart four-factor model by additional factors when it comes to specific categories of equities is often proposed in the literature. Aside from Bird, Liem, and Thorp (2012) with respect to infrastructure indices, Viale, Kolari, and Fraser (2009) extend the Fama/French three-factor model to analyze bank stocks and find that market excess returns and shocks to the slope of the yield curve are sufficient to explain the cross-section of bank returns. Mohandy and Nandha (2011) augment the Carhart four-factor model by two additional factors when examining the cross-section of U.S. oil and gas stocks. The two factors are changes in oil prices and changes in the interest rate. Since energy companies with physical infrastructure and distributional capability are included in our analysis, both factors could be important for our analysis, too. Mohandy and Nandha (2011) find that the oil price has substantial influence on the oil and gas industry, whereas interest rates have no significant effect on the stocks of such companies. Moreover, their results show that companies classified as being in the pipeline subsector are neither sensitive to changes in oil price nor to changes in interest rates. ${ }^{3}$ Following that intuition, we first augment the Carhart four-factor model with the previously mentioned six factors, which should capture the special characteristics of infrastructure stock returns and, hence, explain the return variation of infrastructure investments in more detail. Formally, this infrastructure 10 -factor model is described as:

$$
\begin{aligned}
& R_{i, t}-R_{f, t}=\alpha_{i}+\beta_{i, M}\left(R_{M, t}-R_{f, t}\right)+\beta_{i, S M B} S M B_{t}+\beta_{i, H M L} H M L_{t}+ \\
& \beta_{i, M O M} M_{O} M_{t}+\beta_{i, C F V O L A} C F V O L A_{t}+\beta_{i, L E V} L E V_{t}+\beta_{i, I N V} I N V_{t}+ \\
& \beta_{i, T E R M} T E R M_{t}+\beta_{i, D E F} D E F_{t}+\beta_{i, R E G} R E G_{t}+\epsilon_{i, t},
\end{aligned}
$$

\footnotetext{
${ }^{3}$ Companies that operate pipelines are also part of our dataset. In additional tests we also include changes in oil price in our model, but find no significant results with respect to such a factor. These tests are available upon request.
} 
where the dependent variable is the excess return of infrastructure firms over the U.S. 1-month Treasury bill rate.

Furthermore, we specify an infrastructure seven-factor model that is solely based on the infrastructurespecific characteristics and the market beta, arguing that these factors alone are superior in explaining infrastructure returns compared to the Fama/French three-factor or Carhart four-factor models. The infrastructure seven-factor model is formally defined as:

$$
\begin{aligned}
R_{i, t}-R_{f, t} & =\alpha_{i}+\beta_{i, M}\left(R_{M, t}-R_{f, t}\right)+\beta_{i, C F V O L A} C F V O L A_{t}+ \\
& \beta_{i, L E V} L E V_{t}+\beta_{i, I N V} I N V_{t}+\beta_{i, T E R M} T E R M_{t}+\beta_{i, D E F} D E F_{t}+ \\
& \beta_{i, R E G} R E G_{t}+\epsilon_{i, t} .
\end{aligned}
$$

In the following we discuss the rationale for including each factor in the seven- and 10-factor model, respectively. ${ }^{4}$ Table 2 provides an overview of the relationships we expect between the excess returns of infrastructure investments and all explanatory variables.

\footnotetext{
${ }^{4}$ Next to the full portfolio with all assets, our test assets comprise nine portfolios sorted by size and book-to-market ratio to analyze the sensitivities of our factors in time-series regressions and individual stocks to investigate whether our factors have significant price of risk in the cross-section of stock returns using the Fama-MacBeth (1973) approach. However, note that all factors in our analysis are excess returns and hence the estimate of the factor risk premium corresponds to the sample mean of the factor (Cochrane (2005, p.244)) which does not further require cross-sectional regressions. Using individual stocks in the cross-section is advantageous for two reasons. First, it allows us to create a cross-section that is large enough to be tested (as opposed to a cross-section of portfolios) in order to verify the results from time-series regressions. Second, Ang, Liu, and Schwarz (2010) show that testing individual assets in the cross-section compared to portfolios is superior because the cross-sectional distribution of factor loadings is the most important determinant of the variance of factor risk premia which is most dispersed in the case of individual stocks.
} 
Table 2: Hypotheses

\begin{tabular}{|c|c|c|}
\hline Variable & Hypothesis & Rationale \\
\hline $\mathrm{RM}-\mathrm{Rf}$ & $\begin{array}{l}\text { Positive relation between the mar- } \\
\text { ket and infrastructure returns, but } \\
\text { smaller than } 1 \text {. }\end{array}$ & $\begin{array}{l}\text { Infrastructure should co-move with } \\
\text { the market but be less sensitive } \\
\text { to the overall market given the } \\
\text { constant demand for infrastructure } \\
\text { services (Rothballer and Kaserer } \\
(2012) \text { ). }\end{array}$ \\
\hline SMB & $\begin{array}{l}\text { Negative relation between size effect } \\
\text { and infrastructure returns. }\end{array}$ & $\begin{array}{l}\text { Infrastructure can be considered } \\
\text { as a large-cap industry on average; } \\
\text { thus, a negative relation between } \\
\text { SMB and infrastructure returns } \\
\text { should be observed (Fama and } \\
\text { French }(1997) \text { ). }\end{array}$ \\
\hline HML & $\begin{array}{l}\text { Positive relation between value } \\
\text { effect and infrastructure returns. }\end{array}$ & $\begin{array}{l}\text { Since infrastructure firms do not } \\
\text { offer many growth options, they can } \\
\text { be considered as value stocks; thus, } \\
\text { a positive relation between HML } \\
\text { and returns should be observed. } \\
\text { Bird, Liem, and Thorp (2012) refer } \\
\text { to the "large asset base" resulting } \\
\text { in a positive coefficient on HML. }\end{array}$ \\
\hline Momentum (MOM) & $\begin{array}{l}\text { Positive relation between past re- } \\
\text { turns and infrastructure returns. }\end{array}$ & $\begin{array}{l}\text { Constant (and sustainable) demand } \\
\text { for infrastructure services should } \\
\text { continuously generate positive re- } \\
\text { turns. }\end{array}$ \\
\hline Cash flow volatility (CFVOLA) & $\begin{array}{l}\text { Negative relation between cash flow } \\
\text { volatility and infrastructure returns. }\end{array}$ & $\begin{array}{l}\text { Long-term concessions and inelastic } \\
\text { demand for infrastructure services } \\
\text { (e.g., electricity) should be valued } \\
\text { at a premium by investors. }\end{array}$ \\
\hline Leverage (LEV) & $\begin{array}{l}\text { Positive relation between leverage } \\
\text { and infrastructure returns. }\end{array}$ & $\begin{array}{l}\text { High leverage allows initiating } \\
\text { larger infrastructure projects, which } \\
\text { promise higher returns, but also } \\
\text { more risk, which needs to be com- } \\
\text { pensated. }\end{array}$ \\
\hline Investment growth (INV) & $\begin{array}{l}\text { Positive relation between invest- } \\
\text { ment growth and infrastructure } \\
\text { returns. }\end{array}$ & $\begin{array}{l}\text { Infrastructure firms that invest in } \\
\text { large-scale projects and renew their } \\
\text { physical assets are able to generate } \\
\text { excess returns in the long run. }\end{array}$ \\
\hline Term premium (TERM) & $\begin{array}{l}\text { Positive relation between term } \\
\text { structure and infrastructure returns. }\end{array}$ & $\begin{array}{l}\text { Term premium catches unexpected } \\
\text { changes in interest rates. Infra- } \\
\text { structure's long-term assets (in- } \\
\text { vestments) might be sensitive to } \\
\text { interest rate changes. }\end{array}$ \\
\hline Default premium (DEF) & $\begin{array}{l}\text { Positive relation between default } \\
\text { premium and infrastructure returns. }\end{array}$ & $\begin{array}{l}\text { With increasing default probability, } \\
\text { firms need to pay a risk premium, } \\
\text { especially infrastructure firms with } \\
\text { extensive use of debt. }\end{array}$ \\
\hline Regulatory premium (REG) & $\begin{array}{l}\text { Positive/negative relation between } \\
\text { regulatory risk and infrastructure } \\
\text { returns. }\end{array}$ & $\begin{array}{l}\text { On the one hand, infrastructure } \\
\text { firms are regulated entities that } \\
\text { are bound to predetermined rates } \\
\text { of return. Investors expect a com- } \\
\text { pensation for this restriction. On } \\
\text { the other hand, government can } \\
\text { act as a "lender of last resort" } \\
\text { and help infrastructure firms in } \\
\text { distressed times (Bird, Liem, and } \\
\text { Thorp (2012)). Hence, co-movement } \\
\text { depends on whether capped returns } \\
\text { or assistance in distressed times } \\
\text { dominate. }\end{array}$ \\
\hline
\end{tabular}




\subsection{Cash Flow Volatility}

Including cash flow volatility in our model is based on the assumption that infrastructure firms have stable cash flows because of "long-term sales contracts," low competition due to high entry barriers, and low research and development risk (Sawant (2010); Rothballer and Kaserer (2012)). Following the idea of the CAPM one might expect a positive link between cash flow volatility and returns. Huang (2009) has, however, documented that cash flow volatility is negatively correlated with future stock returns, thereby contradicting the traditional notion that volatility connotes risk. ${ }^{5}$ We analyze ex post returns based on the past historical cash flow volatility and thus also expect to find a negative link.

The existing empirical literature on infrastructure shows mixed results. Bitsch, Buchner, and Kaserer (2010) analyze unlisted infrastructure deals worldwide and the difference in cash outflow volatility between infrastructure and non-infrastructure deals. Their results show that there is no difference in volatility between the two categories. In contrast, Bitsch (2012) finds a difference in cash flow volatility between listed infrastructure and listed non-infrastructure funds. Infrastructure funds have lower cash flow volatility than non-infrastructure funds, and yet investors do not value this stability because cash flow volatility is positively correlated with the fund's value.

\section{$2.2 \quad$ Leverage}

According to the Modigliani-Miller theorem, capital structure should not influence expected returns. The infrastructure sector, however, is driven by high capital requirements to realize large-scale projects, resulting in very high leverage ratios. Bhandari (1988) shows that stock returns are positively correlated with leverage after controlling for market beta, size, and other factors. Under the assumption that leverage does not have the same meaning for different sectors, deviations within a specific sector could have an effect on stocks returns. As Bradley, Jarrell, and Han Kim (1984) show, utility, telecommunication, and transportation companies have by far the highest debt ratios. Rothballer and Kaserer (2012) show that higher financial leverage also has a positive impact on return volatility of infrastructure stocks, meaning that higher leverage increases the risk profile of stocks. ${ }^{6}$

\footnotetext{
${ }^{5}$ These findings underline the results by Ang et al. (2006) for return volatility. Different explanations such as limits to arbirtrage or overconfidence are discussed by Huang (2009), but a credible theoretical explanation for the phenomenon has not yet been developed.

${ }^{6}$ Leverage is taken into consideration by using unlevered betas to examine the market risk of infrastructure stocks. For both the unlevered beta and all other market risk factors (i.e., Dimson beta, world beta, local beta, etc.), the authors find significantly lower factor loadings compared to non-infrastructure firms in the MSCI World Index.
} 
Fama and French (1992) argue that their HML factor accounts for differences in leverage, i.e., HML can be interpreted as an "involuntary leverage effect" that is able to capture the difference between market leverage and book leverage. However, the HML factor does not fully capture the impact of debt because it does not take into consideration the ratio between equity and the more relevant debt value but only the ratio between market and book equity. Higher leverage represents higher risk because there is a larger uncertainty for shareholders about whether payments will be made "due to the seniority of debt claims" (Rothballer and Kaserer (2012)). Hence, we believe that different levels of debt-to-equity ratios lead to substantial differences in the ability to generate cash flows. Leverage should thus be more relevant in explaining the variation of infrastructure returns than the book-to-market ratio, especially given the high significance of debt in infrastructure firms. We expect this relation to be positive because the borrowing of outside capital increases the return on equity.

\subsection{Investment Factor}

There are two key assumptions behind our decision to include an investment factor in the pricing model. First, according to the investment-based asset pricing theory, investments "predict returns because high costs of capital imply low net present values of new capital and [hence] low investment. Low costs of capital, on the other hand, imply high net present values of new capital and thus high investment" (Ammann, Odoni, and Oesch (2012)). This investment factor was first presented by Chen, Novy-Marx, and Zhang (2011) and seems to have superior explanatory power in combination with the market portfolio and a return-on-equity factor than the three-factor model proposed by Fama and French (1993). Second, infrastructure assets are not only characterized by high investment payments, especially at the beginning of their lifecycle; additionally, the very long time horizon of such infrastructure assets implies a high sensitivity toward investment payments. Also, renewing physical infrastructure is profitable only in the long run (Baur et al. (2006)). Thus, investments by infrastructure companies might be an important indicator of profit generation and, thereby, be a good predictor for the variation in equity returns.

\subsection{Term Structure and Default Premium}

We include both a term premium (TERM) and a default premium (DEF), where the term premium indicates changes in the slope of the yield curve and the default premium indicates changes between corporate and government bonds (i.e., the credit risk). The term premium can be interpreted as an 
indicator for unexpected changes in the return of long-term government bonds; the default premium can be interpreted as shifts in the probability of default. Motivated by the high amount of debt, changes in the yield curve might affect the returns of infrastructure companies that are more leveraged than other companies. Also, the term premium compensates investors for "exposure to discount-rate shocks that affect all long-term securities" (Fama and French (1989)), which seems very relevant for long-term infrastructure assets. Sweeney and Warga (1986) regress the stock returns of 21 industry portfolios against the market and a series of simple changes in long-term interest rates. They find that it is only the stocks of electric utilities and the banking, finance, and real estate industry that are consistently sensitive to interest rates over the period 1960 to 1979 . O'Neal (1998) confirms these results for electric utility firms.

According to Ang, Bekaert, and Wei (2008), an "inflation risk premium that increases with maturity fully accounts for the generally upward sloping nominal term structure." Hence, changes in the term structure might also be the result of shocks in the inflation risk premium. Term structure might then be a good approximation for the hedging abilities of infrastructure toward an inflation effect or at least be highly correlated with inflation. The inflation aspect of infrastructure is examined by Rödel and Rothballer (2012), who, based on a set of global infrastructure stocks, find that infrastructure is not able to hedge against inflation. In contrast, Bird, Liem, and Thorp (2012) find some evidence that the utility industry is able to hedge inflation, while the telecommunication industry (represented by the UBS Infrastructure Index) cannot.

Furthermore, the default premium might shed some light on the return profile of infrastructure firms during distressed times. We expect that there is a positive link between the default premium and stock returns, since increasing default probability increases the risk for investors. This might be especially pronounced for infrastructure firms, which typically use a lot of debt and, hence, are more affected by credit risk.

\subsection{Regulatory Premium}

The regulatory risk premium has two facets that are in opposition to each other. On the one hand, as Bird, Liem, and Thorp (2012) point out, infrastructure is somewhat protected by the government because it is vital to communities and the economy. It could thus be argued that "investors hold a put option to sell assets back to the government if the asset price declines" (Bird, Liem, and Thorp (2012)). On the 
other hand, large infrastructure companies are typically capped by governmental regulation with respect to the rate of return or prices so as to prevent excessive exploitation of monopolistic power. ${ }^{7}$ Depending on which effect dominates in the long run, investors might be compensated for the respective effect or both effects could cancel each other out.

\section{Data and Summary Statistics}

\subsection{Data Selection}

Two of the major issues researchers face when analyzing infrastructure investments are the sparse data availability and the question of which infrastructure investment vehicle to analyze. We choose to analyze listed infrastructure because it has the most reliable dataset, which is crucial for our factor construction. Also, the long timeframe allows us to show the risk and return profile of infrastructure investments in the long run. Further, unlike equity infrastructure indices, we neither determine a specific liquidity level nor a certain market capitalization for our dataset. This means we are able to analyze the entire scope of infrastructure stocks without limitations.

Our definition of infrastructure follows that of Rothballer and Kaserer (2012) and thus comprises the utility, communication, and transportation industries. ${ }^{8}$ Also in line with Rothballer and Kaserer (2012), we consider only companies that act as network operators and have either their own physical infrastructure or a concession to use physical infrastructure. Thus, contractors (e.g., construction firms) and other service providers (e.g., maintenance services) who depend on operators are excluded from this definition. Our dataset includes all U.S. infrastructure stocks with SIC and GIC codes related to utilities, telecommunication, and transportation available on the CRSP and in the COMPUSTAT database. ${ }^{9}$ Our analysis starts in January 1980 and ends in December 2011, yielding 384 monthly observations. The restrictive element in our dataset is the availability of large-scale quarterly data in COMPUSTAT, which we need for calculating a rolling standard deviation for the cash flow volatility factor.

To identify companies that own or operate physical infrastructure assets we apply a textual analysis of

\footnotetext{
${ }^{7}$ For example, the rate-of-return regulation prevails in the U.S. for electricity, gas, and water utilities (Beecher and Kalmbach (2013)).

${ }^{8}$ Although infrastructure can also comprise social infrastructure (e.g., schools, hospitals, and prisons), we do not include these types of "companies" in our dataset due to scarce data availability and the predominantly nonprofit focus of social infrastructure.

${ }^{9}$ Our selection of SIC and GIC codes is based on Rothballer and Kaserer (2012).
} 
business descriptions from various sources (Thomson Worldscope (WC06092), SEC filings (10-K, 10-Q, S-1 filings), Bloomberg company overviews, and corporate websites). The actual company names are deleted in the textual analysis to avoid a precipitant assignment of companies that contain words such as "Energy" or "Utilities" in their trade name and which could occur in the same sentence as further textual conditions. As a result, this method is able to differentiate between companies (theoretically) generating stable cash flows through their physical assets and companies that are contractors or service providers. Furthermore, we include only those firms with ordinary common equity listed on the NYSE, AMEX, or NASDAQ. Hence, ADRs, REITs, and units of beneficial interest are excluded. We also exclude all stocks that do not have at least 24 months of consecutive return data and we do not consider firms with negative book values. All accounting data are retrieved from COMPUSTAT. The book common equity is calculated as the book value of stockholders' equity plus deferred taxes and investment tax credits subtracted from the book value of preferred stocks.

\subsection{Construction of Explanatory Variables}

We construct a mimicking portfolio for cash flow volatility based on quarterly observations over a rolling three-year period. To be included in the calculation, a company must have at least eight non-missing values within that estimation window (Huang (2009)). We calculate the rolling standard deviation on standardized cash flow volatility and define cash flow as income before extraordinary items (COMPUSTAT item ibq) plus depreciation and amortization (item dpq) plus the quarterly change in working capital (item wcapq $[t]-$ wcapq $[t-3$ months $]$ ). ${ }^{10}$

Using quarterly, as compared to annual, data enables us to increase the number of observations and improves the calculation of the standard deviation. To analyze ex post returns based on the past historical cash flow volatility and to make sure that accounting information from quarterly reports is known prior to stock market development, we match three-month lagged accounting data (i.e., the previous fiscal quarter) with stock returns. Hence, we assume that it takes about three months until quarterly accounting data are available to the public. This method is identical to that employed by Huang (2009). Having calculated the standard deviation of cash flows from $t$ to $t$-36 months divided by sales in $t$ we then rank

\footnotetext{
${ }^{10}$ Both deferred taxes and preferred taxes are largely missing in the quarterly dataset, which is why we do not include these items in the determination of cash flows (see Huang (2009)).
} 
each company according to the ratio of cash flow volatility and sales (CF/sales). ${ }^{11}$ We create breakpoints for the bottom $30 \%$ (low $\mathrm{CF} /$ sales), middle $40 \%$ (medium $\mathrm{CF} /$ sales), and top 30\% (high CF/sales) based on infrastructure firms listed on the NYSE, following Fama and French's (1993) approach to defining breakpoints. ${ }^{12}$ In each month we assign all stocks to those three $\mathrm{CF} /$ sales groups based on the ranked values of $\mathrm{CF} /$ sales. Furthermore, we create six portfolios in each month based on the intersection between low $\mathrm{CF} /$ sales, middle $\mathrm{CF}$ /sales, and high $\mathrm{CF}$ /sales, as well as small and big market capitalization. ${ }^{13}$ For each portfolio value-weighted returns are calculated. The mimicking portfolio is then the difference between the average return of the two high $\mathrm{CF}$ /sales portfolios and the average return of the two low $\mathrm{CF} /$ sales portfolios. Hence, our cash flow volatility factor indicates whether there is a premium being paid to investors if cash flows do not vary extensively over time.

The investment factor (INV) is calculated as the difference between a return portfolio of low investment growth and high investment growth. This investment factor is identical to the factor proposed by Chen, Novy-Marx, and Zhang (2011). Furthermore, we construct a high minus low debt-to-equity ratio factor defined as $D E R_{t}=\frac{\text { bookvalue of total assets } t_{-1}-\text { book value of common equity } t_{-1}}{\text { market value of common equity } y_{t-1}}$ (see Bhandari (1988)). In June of year $t$ we sort all stocks according to their DER based on NYSE breakpoints. Stocks with low debt-toequity ratios are in the bottom $30 \%$ and stocks with high debt-to-equity ratios in the top $30 \%$. We also include two portfolios for small and large stocks. From the intersection of the DER and size portfolios we calculate value-weighted returns from July in year $t$ to June of year $t+1$. We rebalance each portfolio in June of year $t+1$. The difference between the average return of the two high DER portfolios and the average return of the two low DER portfolios establishes our leverage factor LEV.

The definitions of the TERM and DEF factors are identical to those in Fama and French (1993). TERM is constructed as the monthly difference between long-term bond returns of the U.S. government and the one-month T-bill rate (retrieved from CRSP). The DEF factor is calculated as the spread between the return on a long-term corporate bond index (i.e., Barclays U.S. Aggregate Long-Term Corporate Bond Index BAA) and the return on the long-term government bond index. The regulatory risk premium REG is constructed as the return spread between a utility bond index and an overall industrial bond index. ${ }^{14}$

\footnotetext{
${ }^{11}$ Since we construct portfolios based on the ranking of cash flow volatility, we do not consider it necessary to winsorize cash flows.

${ }^{12}$ Fama and French (1993) argue that the market value of NASDAQ and AMEX stocks is in general much smaller, which is why NYSE breakpoints guarantee a certain amount of market capitalization in each portfolio.

${ }^{13}$ We control for size in construction of the cash flow volatility factor because Minton and Schrand (1999) show that small firms tend to be more cash flow volatile.

${ }^{14}$ The utility bond index refers to the Citigoup Utility Index (Total Return) and the industrial bond index refers to the Citigroup Industrial Index (Total Return).
} 
The comparable average maturity and default risk of both indices guarantee that the spread does not capture a term or default risk premium. The return difference between a utility bond and an industrial bond ought to capture the remaining regulatory impact on utility firms. ${ }^{15}$

Finally, we include RM-Rf, SMB, HML, and MOM (in line with Fama and French (1993) and Carhart (1997)). Data for these factors can be downloaded from Kenneth French's website (http://mba.tuck . dartmouth.edu/pages/faculty/ken.french/data_library.html). The remaining data are taken from CRSP, COMPUSTAT, and Thomson Reuters Datastream.

\subsection{Summary Statistics}

Panel A of Table 3 presents summary statistics for a value-weighted infrastructure index (VWI Index) in excess of the risk-free rate based on the entire sample and summary statistics for nine excess return portfolios sorted by size and book-to-market ratio. Panel B presents summary statistics for the 10 factors we use as explanatory variables. Our total dataset includes 396 companies over the entire sample period. Comparing the VWI index with the market return $\left(R_{M}-R_{f}\right)$, reveals that infrastructure stocks on average offer a slightly lower return with a lower standard deviation. The portfolio returns of infrastructure stocks on average decrease with increasing market equity, while portfolio returns climb with increasing bookto-market equity, except for the intersection of the largest book-to-market and size portfolio. This is in line with previous findings showing higher returns for small and value stocks (see, e.g., Fama and French (1993); Bauman, Conover, and Miller (1998)). It is, however, also a first indication that large infrastructure firms do not necessarily exploit their monopolistic structure because large infrastructure firms do not outperform smaller ones.

\footnotetext{
${ }^{15}$ We acknowledge that the use of a utility bond index is only an approximation for infrastructure bonds in general. However, the lack of such data and the large percentage of utility companies in commercial infrastructure indices might justify such an approach. Using an option-like factor to account for the regulatory risk is also conceivable, but historic prices do not suffice to construct such a factor. See Bird, Liem and Thorp (2012) for a more thorough discussion of the impact of regulatory power.
} 
Table 3: Summary statistics

\begin{tabular}{|c|c|c|c|c|c|c|c|c|c|c|}
\hline \multirow[b]{2}{*}{ Variable } & \multirow{2}{*}{$\begin{array}{l}\text { Infrastructure index } \\
V W I \text { index }\end{array}$} & \multicolumn{9}{|c|}{$\begin{array}{l}\text { Portfolio excess returns with } 3 \text { small and } 3 \mathrm{BE} / \mathrm{ME} \text { groups (first figure denotes: small } \\
\text { (1) to large (3) portfolios and second figure denotes: low } \mathrm{BE} / \mathrm{ME} \text { (1) to high } \mathrm{BE} / \mathrm{ME} \\
\text { (3) portfolios) }\end{array}$} \\
\hline & & $P 1 / 1$ & $P 2 / 1$ & $P 3 / 1$ & $P 1 / 2$ & $P 2 / 2$ & $P 3 / 2$ & $P 1 / 3$ & $P 2 / 3$ & P 3/3 \\
\hline Mean & 0.50 & 0.57 & 0.55 & 0.43 & 0.81 & 0.67 & 0.62 & 0.88 & 0.84 & 0.62 \\
\hline Std. dev. & 3.93 & 5.03 & 4.74 & 5.29 & 3.52 & 4.08 & 4.31 & 4.50 & 4.24 & 4.60 \\
\hline Min & -13.63 & -25.49 & -21.43 & -18.12 & -13.80 & -14.22 & -13.38 & -20.02 & -20.80 & -26.50 \\
\hline Max & 12.24 & 25.30 & 15.81 & 16.95 & 10.67 & 14.24 & 15.13 & 18.81 & 11.22 & 13.68 \\
\hline $\begin{array}{l}\text { \# of stocks } \\
\text { (monthly average) }\end{array}$ & 161.6 & 30.7 & 15.2 & 10.8 & 27.5 & 19.3 & 13.4 & 21.3 & 13.0 & 10.4 \\
\hline PANEL B & Independent variables & & & & & & & & & \\
\hline Variable & $R M-R f$ & $S M B$ & $H M L$ & MOM & CFVOLA & $L E V$ & $I N V$ & TERM & $D E F$ & $R E G$ \\
\hline Mean & 0.55 & 0.15 & 0.32 & 0.65 & 0.11 & 0.36 & 0.16 & 0.42 & 0.02 & 0.02 \\
\hline Std. dev. & 4.64 & 3.14 & 3.13 & 4.72 & 2.41 & 3.11 & 2.25 & 3.75 & 2.14 & 0.70 \\
\hline Min & -23.14 & -16.62 & -12.87 & -34.75 & -9.78 & -14.56 & -6.73 & -14.74 & -11.12 & -4.97 \\
\hline Max & 12.43 & 22.06 & 13.88 & 18.40 & 9.61 & 12.08 & 8.61 & 17.33 & 10.17 & 2.92 \\
\hline $\mathrm{T}$ (months) & 384 & 384 & 384 & 384 & 384 & 384 & 384 & 384 & 384 & 384 \\
\hline
\end{tabular}

Table 4 presents a correlation matrix of all dependent and independent factors. The correlation between HML and LEV is significant and positive (0.47), which is a meaningful finding since both ratios include the book value of equity in the nominator and the market value of equity in the denominator. However, the value of 0.47 also shows that there are substantial differences between the two factors so that HML will not absorb the explanatory power of LEV (multicollinearity is rejected). Moreover, we find a significant negative correlation (-0.53) between TERM and DEF that seems slightly higher than in previous studies. Peterson and Hsieh (1997), for example, find a correlation of -0.43 for the period 1976 - 1992. None of the correlations are extensive enough to cause multicollinearity issues. The correlation between the market return and dependent VWI Index seem to co-move extensively with a correlation of 0.82 . 


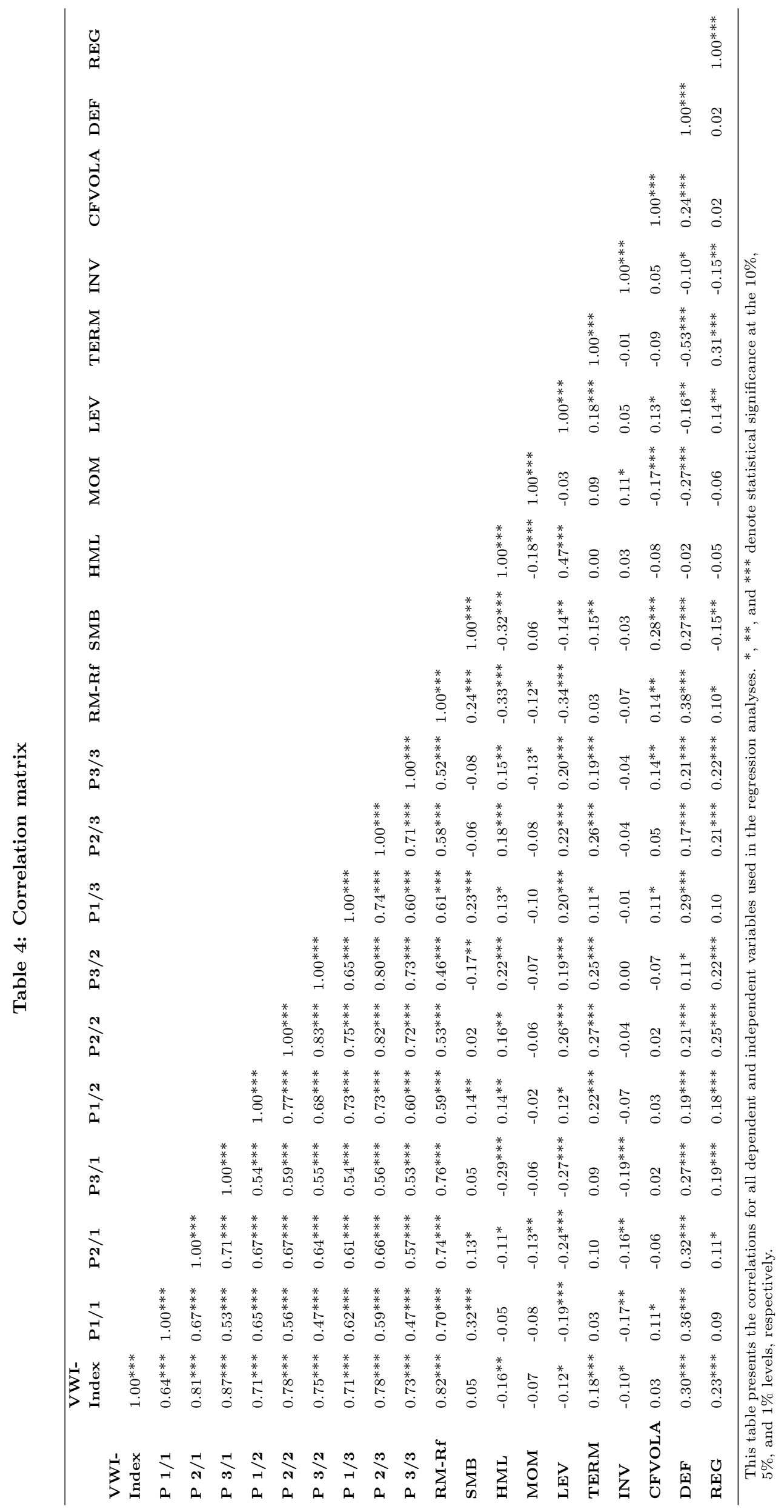




\section{Empirical Results}

\subsection{Main Results from Time Series Regressions}

Table 5 shows regression results for different factor models with the VWI Index as the dependent variable. ${ }^{16}$ The market beta is significant in all models and between 0.69 (CAPM) and 0.76 (Carhart four-factor model), suggesting a defensive reaction by infrastructure stocks to overall market movements.

Table 5: Time series regressions using value-weighted infrastructure index as dependent variable

\begin{tabular}{|c|c|c|c|c|c|}
\hline Variables & $\begin{array}{c}(1) \\
\text { CAPM }\end{array}$ & $\begin{array}{c}\text { (2) } \\
\text { FF 3-factor model }\end{array}$ & $\begin{array}{c}(3) \\
\text { Carhart } 4 \text {-factor model }\end{array}$ & $\begin{array}{l}(4) \\
\text { Infrastructure } \\
7 \text {-factor model }\end{array}$ & $\begin{array}{l}(5) \\
\text { Infrastructure } \\
\text { 10-factor model }\end{array}$ \\
\hline$\beta_{M}$ & $\begin{array}{c}0.693^{* * *} \\
(0.0288)\end{array}$ & $\begin{array}{l}0.747^{* * *} \\
(0.0314)\end{array}$ & $\begin{array}{c}0.757^{* * *} \\
(0.0316)\end{array}$ & $\begin{array}{l}0.703^{* * *} \\
(0.0275)\end{array}$ & $\begin{array}{l}0.725^{* * *} \\
(0.0274)\end{array}$ \\
\hline$\beta_{S M B}$ & & $\begin{array}{c}-0.172^{* * *} \\
(0.0429)\end{array}$ & $\begin{array}{c}-0.175^{* * *} \\
(0.0413)\end{array}$ & & $\begin{array}{l}-0.146^{* * *} \\
(0.0452)\end{array}$ \\
\hline$\beta_{H M L}$ & & $\begin{array}{l}0.117^{* *} \\
(0.0501)\end{array}$ & $\begin{array}{c}0.134^{* * *} \\
(0.0470)\end{array}$ & & $\begin{array}{l}0.0495 \\
(0.0467)\end{array}$ \\
\hline$\beta_{M O M}$ & & & $\begin{array}{c}0.0477 \\
(0.0298)\end{array}$ & & $\begin{array}{l}0.0517^{*} \\
(0.0305)\end{array}$ \\
\hline$\beta_{C F V O L A}$ & & & & $\begin{array}{l}-0.203^{* * *} \\
(0.0476)\end{array}$ & $\begin{array}{l}-0.138^{* * *} \\
(0.0496)\end{array}$ \\
\hline$\beta_{L E V}$ & & & & $\begin{array}{l}0.197^{* * *} \\
(0.0468)\end{array}$ & $\begin{array}{l}0.168^{* * *} \\
(0.0525)\end{array}$ \\
\hline$\beta_{I N V}$ & & & & $\begin{array}{l}-0.0440 \\
(0.0572)\end{array}$ & $\begin{array}{l}-0.0615 \\
(0.0566)\end{array}$ \\
\hline$\beta_{T E R M}$ & & & & $\begin{array}{l}0.170^{* * *} \\
(0.0464)\end{array}$ & $\begin{array}{l}0.173^{* * *} \\
(0.0446)\end{array}$ \\
\hline$\beta_{D E F}$ & & & & $\begin{array}{l}0.218^{* * *} \\
(0.0698)\end{array}$ & $\begin{array}{l}0.267^{* * *} \\
(0.0737)\end{array}$ \\
\hline$\beta_{R E G}$ & & & & $\begin{array}{l}0.411^{* *} \\
(0.166)\end{array}$ & $\begin{array}{l}0.328^{*} \\
(0.170)\end{array}$ \\
\hline$\alpha$ & $\begin{array}{c}0.119 \\
(0.116)\end{array}$ & $\begin{array}{l}0.0767 \\
(0.112)\end{array}$ & $\begin{array}{l}0.0355 \\
(0.114)\end{array}$ & $\begin{array}{l}-0.0315 \\
(0.106)\end{array}$ & $\begin{array}{c}-0.0486 \\
(0.105)\end{array}$ \\
\hline $\begin{array}{l}\text { Monthly obs. } \\
\text { Adj. } \mathrm{R}^{2}\end{array}$ & $\begin{array}{c}384 \\
66.9 \%\end{array}$ & $\begin{array}{c}384 \\
69.9 \%\end{array}$ & $\begin{array}{c}384 \\
70.1 \%\end{array}$ & $\begin{array}{l}384 \\
73.7 \%\end{array}$ & $\begin{array}{l}384 \\
75.0 \%\end{array}$ \\
\hline
\end{tabular}

This table reports factor loadings from time series regressions for the CAPM (Column 1), the Fama/French three-factor (Column 2), the Carhart four-factor model (Column 3), the infrastructure seven-factor model (Column 4), and the infrastructure 10-factor model as an augmented version of the Carhart four-factor model (Column 5). The sample period is January 1980 to December 2011 (384 monthly observations). The adjusted $R^{2}$ values from each time series are reported at the end of the table. Standard errors are reported in parentheses and are computed using the Newey-West (1987) correction for heteroscedasticity and serial correlation. $*, * *$, and $* * *$ denote statistical significance at the $10 \%, 5 \%$, and $1 \%$ levels, respectively.

In contrast to Bird, Liem, and Thorp (2012), who find no significant effect in the SMB factor, our negative and significant loading on the SMB factor indicates that the infrastructure sector behaves like a large company sector, which is in line with Fama and French's (1997) findings that the SMB factor loads

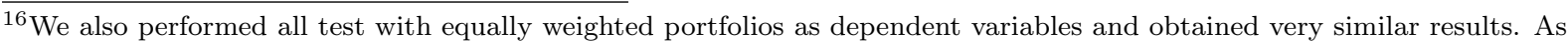
expected, the SMB factor takes on positive factor loadings in that case due to each stock being equally weighted instead of value weighted. The detailed tests are available from the authors upon request.
} 
negatively the higher the average industry size. ${ }^{17}$ The HML factor is significant for the Fama/French three- and Carhart four-factor models, but is not significant in the infrastructure 10-factor model because of the inclusion of the leverage factor, which actually absorbs the explanatory power of the HML factor for infrastructure firms. It thus seems that LEV is better able to capture the variation in infrastructure returns than is HML. The leverage effect is significantly positive in all model specifications, meaning that investors receive a positive risk premium for infrastructure firms with high debt-to-equity ratios. A $1 \%$ increase in the spread of high and low leverage firms would result in a $0.168 \%$ to $0.197 \%$ monthly increase in the expected return of infrastructure firms.

Regarding the momentum factor, we find a weakly significant and positive relation for infrastructure returns in the infrastructure 10-factor model, suggesting that past winners continue to outperform past losers. The investment factor (INV) performs rather poorly in explaining the return variation of infrastructure stocks. Given the results by Chen, Novy-Marx, and Zhang (2011), and the large-scale upfront investments that infrastructure firms have to make, we would have expected a significantly positive relation between INV and expected returns. However, the results are not significant.

The coefficients of the two bond factors TERM and DEF are positive and significant in both the infrastructure seven-factor model and the infrastructure 10-factor model. The average term premium is economically relevant and indicates an average risk premium of $0.1 \%$ per month (slope of the TERM factor times mean TERM premium). The average premium of default risk is positive but close to zero. The results on the term and default factor imply that infrastructure stocks are interest rate sensitive and have characteristics similar to those of bond investments to some extent.

The regulatory risk premium (REG) is positive and significant, suggesting that infrastructure firms are more affected by capped returns than by governmental support in times of financial distress.

CFVOLA is overall negative and significant at $1 \%$ level, which indicates that investors value the cash flow stability of infrastructure firms. Though this result is in line with findings about the negative relation of returns and volatility in stocks (see Rountree, Weston, and Allayannis (2008); Huang (2009)), our result shows that the economic magnitude is small, with a monthly cash flow stability premium of $0.02 \%$. Nevertheless, the large standard deviation of $2.4 \%$ per month (see Table 3 ) helps explain the variation in stock returns despite the low average premium.

According to the adjusted R-square, the infrastructure seven-factor model performs better than the

\footnotetext{
${ }^{17}$ Robustness tests in Appendix A and B show results using a different data sample (i.e. commercial infrastructure indices).
} Amongst other results these tests also confirm the overall significant and negative loading on the SMB factor. 
Carhart four-factor model. ${ }^{18}$ The infrastructure 10 -factor model adds slightly more explanatory power $(1.3 \%)$ to the infrastructure seven-factor model. The results on the infrastructure seven-factor model are interesting because, despite the focus on infrastructure firms, the underlying investment vehicle is still equity. The fact that our seven-factor infrastructure model explains a specific category of stocks better than the Fama/French three-factor model corroborates the finding from other studies that industries or sectors contain additional information about stock returns that is not captured by the Fama/French factors (see, e.g., Chou, Ho, and Ko (2012); Fama and French (1997)). A combination of the Carhart factors and the sector-specific factors results in the highest explanatory power, but also in a very large model. For this reason, some might favor the reduced seven-factor model to avoid a potential overfit. Having tested the model with respect to the value-weighted sum of excess returns (i.e., the VWI Index) as the dependent variable we now turn to a more detailed analysis using nine portfolios sorted by size and book-to-market ratio in order to better understand the role of size and book-to-market ratio in an infrastructure context and to account for the possibility that some characteristic portfolios are more difficult to price, such as the small growth portfolio (Vassalou (2003)). Similar to the regressions shown in Table 5, the market betas in Table 6 are smaller than 1 in all nine portfolios, confirming the results of Rothballer and Kaserer (2012) that infrastructure poses low market risk.

\footnotetext{
${ }^{18}$ The F-statistic for specification errors (Ramsey RESET test) in our seven- and 10-factor infrastructure models indicates that the functional form of our models is correctly specified. The null hypothesis of the RESET test is that the model has no omitted variables. We do not reject the null, with a p-value of 0.38 for the infrastructure seven-factor model and a p-value of 0.23 for the infrastructure 10-factor model compared to a p-value of 0.15 for the Carhart four-factor model.
} 
Table 6: Standard CAPM factor loadings from time series regressions: $R_{i, t}-R_{f, t}=\alpha_{i}+\beta_{i, M}\left(R_{M, t}-\right.$ $\left.R_{f, t}\right)+\epsilon_{i, t}$

\begin{tabular}{|c|c|c|c|c|}
\hline Variables & & Low & 2 & High \\
\hline \multirow[t]{3}{*}{$\beta_{M}$} & Small & $\begin{array}{l}0.761 * * * \\
(0.0649)\end{array}$ & $\begin{array}{l}0.447 * * * \\
(0.0377)\end{array}$ & $\begin{array}{l}0.593^{* * *} \\
(0.0472)\end{array}$ \\
\hline & 2 & $\begin{array}{l}0.753^{* * *} \\
(0.0439)\end{array}$ & $\begin{array}{l}0.464^{* * *} \\
(0.0503)\end{array}$ & $\begin{array}{l}0.533^{* * *} \\
(0.0511)\end{array}$ \\
\hline & Big & $\begin{array}{l}0.865 * * * \\
(0.0488)\end{array}$ & $\begin{array}{l}0.425 * * * \\
(0.0581)\end{array}$ & $\begin{array}{l}0.511^{* * *} \\
(0.0739)\end{array}$ \\
\hline \multirow[t]{3}{*}{$\alpha$} & Small & $\begin{array}{l}0.154 \\
(0.163)\end{array}$ & $\begin{array}{l}0.561 * * * \\
(0.146)\end{array}$ & $\begin{array}{l}0.548^{* * *} \\
(0.203)\end{array}$ \\
\hline & 2 & $\begin{array}{l}0.136 \\
(0.164)\end{array}$ & $\begin{array}{l}0.416^{* *} \\
(0.193)\end{array}$ & $\begin{array}{l}0.547^{* * *} \\
(0.185)\end{array}$ \\
\hline & Big & $\begin{array}{l}-0.0444 \\
(0.183)\end{array}$ & $\begin{array}{l}0.385^{*} \\
(0.199)\end{array}$ & $\begin{array}{l}0.338 \\
(0.231)\end{array}$ \\
\hline \multirow[t]{3}{*}{ Adj. $R^{2}$} & Small & $49.2 \%$ & $34.6 \%$ & $37.3 \%$ \\
\hline & 2 & $54.3 \%$ & $27.8 \%$ & $33.9 \%$ \\
\hline & Big & $57.6 \%$ & $20.8 \%$ & $26.4 \%$ \\
\hline \multicolumn{5}{|c|}{$\begin{array}{l}\text { GRS test statistic } \\
=2.22 \\
\mathrm{p}(\mathrm{GRS})=0.020\end{array}$} \\
\hline
\end{tabular}

This table reports factor loadings on the market factor (RM-RF) for nine portfolios sorted by size (ME) and book-to-market equity (BE/ME). The intercepts of each portfolio are reported in the middle of the table. The sample period is January 1980 to December 2011 (384 monthly observations). The GRS test statistics and the adjusted $R^{2}$ values from each time series are reported at the end of the table. Standard errors are reported in parentheses and are computed using the Newey-West (1987) correction for heteroscedasticity and serial correlation. $* * *$, and $* * *$ denote statistical significance at the $10 \%, 5 \%$, and $1 \%$ levels, respectively.

The low R-square also suggests high idiosyncratic risk, which can now be itemized by our identified risk factors. The least well explained variation of returns occurs at the intersection of large stocks and medium/high book-to-market stocks, where only $20.8 \%$ and $26.4 \%$, respectively, of the variation in infrastructure stocks is explained. The GRS test statistic also rejects the null that the intercepts of the portfolios are jointly zero, which indicates that additional factors are necessary to price infrastructure firms.

For the Fama/French model (see Table 7) we see a strong increase in the explanatory power across all nine portfolios, especially for the large, medium book-to-market portfolio where the R-square almost doubles (from $20.8 \%$ to $39.7 \%$ ). 
Table 7: Fama/French factor loadings from time series regressions: $R_{i, t}-R_{f, t}=\alpha_{i}+\beta_{i, M}\left(R_{M, t}-\right.$ $\left.R_{f, t}\right)+\beta_{i, S M B} S M B_{t}+\beta_{i, H M L} H M L_{t}+\epsilon_{i, t}$

\begin{tabular}{|c|c|c|c|c|c|c|c|c|}
\hline Variables & & Low & 2 & High & & Low & 2 & High \\
\hline \multirow[t]{3}{*}{$\beta_{M}$} & Small & $\begin{array}{l}0.796^{* * *} \\
(0.0499)\end{array}$ & $\begin{array}{l}0.529^{* * *} \\
(0.0351)\end{array}$ & $\begin{array}{l}0.684^{* * *} \\
(0.0393)\end{array}$ & \multirow[t]{3}{*}{$\beta_{S M B}$} & $\begin{array}{l}0.359^{* * *} \\
(0.0631)\end{array}$ & $\begin{array}{l}0.110^{* *} \\
(0.0532)\end{array}$ & $\begin{array}{l}0.272^{* * *} \\
(0.0616)\end{array}$ \\
\hline & 2 & $\begin{array}{l}0.806^{* * *} \\
(0.0378)\end{array}$ & $\begin{array}{l}0.578^{* * *} \\
(0.0520)\end{array}$ & $\begin{array}{l}0.675^{* * *} \\
(0.0418)\end{array}$ & & $\begin{array}{l}-0.0258 \\
(0.0859)\end{array}$ & $\begin{array}{l}-0.0316 \\
(0.0965)\end{array}$ & $\begin{array}{l}-0.155^{* * *} \\
(0.0549)\end{array}$ \\
\hline & Big & $\begin{array}{l}0.878^{* * *} \\
(0.0496)\end{array}$ & $\begin{array}{l}0.583^{* * *} \\
(0.0481)\end{array}$ & $\begin{array}{l}0.652^{* * *} \\
(0.0735)\end{array}$ & & $\begin{array}{l}-0.266^{* * *} \\
(0.0693)\end{array}$ & $\begin{array}{l}-0.279 * * * \\
(0.0679)\end{array}$ & $\begin{array}{l}-0.202^{* * *} \\
(0.0751)\end{array}$ \\
\hline \multirow[t]{3}{*}{$\beta_{H M L}$} & Small & $\begin{array}{l}0.420^{* * *} \\
(0.101)\end{array}$ & $\begin{array}{l}0.448^{* * *} \\
(0.0647)\end{array}$ & $\begin{array}{l}0.604^{* * *} \\
(0.0690)\end{array}$ & \multirow[t]{3}{*}{$\alpha$} & $\begin{array}{c}-0.0542 \\
(0.145)\end{array}$ & $\begin{array}{l}0.355^{* * *} \\
(0.135)\end{array}$ & $\begin{array}{l}0.263 \\
(0.161)\end{array}$ \\
\hline & 2 & $\begin{array}{l}0.219^{* *} \\
(0.0916)\end{array}$ & $\begin{array}{l}0.482^{* * *} \\
(0.0821)\end{array}$ & $\begin{array}{l}0.522^{* * *} \\
(0.0734)\end{array}$ & & $\begin{array}{l}0.0400 \\
(0.171)\end{array}$ & $\begin{array}{l}0.204 \\
(0.176)\end{array}$ & $\begin{array}{l}0.324^{* *} \\
(0.162)\end{array}$ \\
\hline & Big & $\begin{array}{c}-0.133^{* *} \\
(0.0672)\end{array}$ & $\begin{array}{l}0.501^{* * *} \\
(0.0899)\end{array}$ & $\begin{array}{l}0.481^{* * *} \\
(0.0948)\end{array}$ & & $\begin{array}{l}0.0303 \\
(0.177)\end{array}$ & $\begin{array}{l}0.179 \\
(0.171)\end{array}$ & $\begin{array}{l}0.135 \\
(0.218)\end{array}$ \\
\hline \multirow[t]{3}{*}{ Adj. $R^{2}$} & Small & $57.0 \%$ & $47.6 \%$ & $52.4 \%$ & & & & \\
\hline & 2 & $56.1 \%$ & $40.3 \%$ & $50.2 \%$ & & & & \\
\hline & Big & $59.7 \%$ & $39.7 \%$ & $39.6 \%$ & & & & \\
\hline \multicolumn{9}{|c|}{$\begin{array}{l}\text { GRS test statistic } \\
=1.28 \\
\mathrm{p}(\mathrm{GRS})=0.248\end{array}$} \\
\hline
\end{tabular}

For the other portfolios, the additional explanatory power by the Fama/French model in excess of the CAPM model ranges between an increase of 1.8 percentage points (from $54.3 \%$ to $56.1 \%$ ) and 16.3 percentage points (from $33.9 \%$ to $50.2 \%$ ). The GRS test statistics cannot reject the null hypothesis that the intercepts are jointly zero, but the low R-square values suggest that there might be other variables that could increase the explanatory power.

Regarding the infrastructure seven-factor model, Table 8 reveals a strong increase in the R-square compared to the Fama/French model, except for the small/growth portfolio, for which we observe a decrease of 5.2 percentage points. The increase ranges between 0.7 percentage points $(60.4 \%$ vs. $59.7 \%)$ in the large/growth portfolio and 15.5 percentage points in the medium size/medium book-to-market portfolio. The GRS test statistics cannot reject the null that the intercepts are jointly different from zero and the test value is lower than in the Fama/French case, supporting the idea that the model better predicts infrastructure returns. 
Table 8: Infrastructure asset class factor model from time series regressions: $R_{i, t}-R_{f, t}=$ $\alpha_{i}+\beta_{i, M}\left(R_{M, t}-R_{f, t}\right)+\beta_{i, C F V O L A} C F V O L A_{t}+\beta_{i, L E V} L E V_{t}+\beta_{i, I N V} I N V_{t}+\beta_{i, T E R M T E R M_{t}}+$ $\beta_{i, D E F} D E F_{t}+\beta_{i, R E G} R E G_{t}+\epsilon_{i, t}$

\begin{tabular}{|c|c|c|c|c|c|c|c|c|}
\hline Variables & & Low & 2 & High & & Low & 2 & High \\
\hline \multirow[t]{5}{*}{$\beta_{M}$} & Small & $\begin{array}{l}0.702 * * * \\
(0.0429)\end{array}$ & $\begin{array}{l}0.505 * * * \\
(0.0344)\end{array}$ & $\begin{array}{l}0.698 * * * \\
(0.0491)\end{array}$ & \multirow[t]{5}{*}{$\beta_{L E V}$} & $\begin{array}{l}0.0877 \\
(0.109)\end{array}$ & $\begin{array}{l}0.387 * * * \\
(0.0475)\end{array}$ & $\begin{array}{l}0.685 * * * \\
(0.0630)\end{array}$ \\
\hline & 2 & $0.712^{* * *}$ & $0.538^{* * *}$ & $0.643^{* * *}$ & & 0.0461 & $0.611^{* * *}$ & $0.617^{* * *}$ \\
\hline & & $(0.0343)$ & $(0.0446)$ & $(0.0471)$ & & $(0.0642)$ & $(0.0634)$ & $(0.0677)$ \\
\hline & Big & $0.840 * * *$ & $0.526 * * *$ & $0.584 * * *$ & & -0.0426 & $0.536 * * *$ & $0.564 * * *$ \\
\hline & & $(0.0571)$ & $(0.0524)$ & $(0.0510)$ & & $(0.0848)$ & $(0.0921)$ & $(0.0817)$ \\
\hline \multirow[t]{6}{*}{$\beta_{C F V O L A}$} & Small & -0.0228 & $-0.179^{* * *}$ & $-0.170^{* *}$ & \multirow[t]{6}{*}{$\beta_{I N V}$} & $-0.250^{* *}$ & -0.0309 & 0.0605 \\
\hline & & $(0.103)$ & $(0.0624)$ & $(0.0716)$ & & $(0.101)$ & $(0.0600)$ & $(0.0734)$ \\
\hline & 2 & $-0.358 * * *$ & $-0.262^{* * *}$ & $-0.202^{* * *}$ & & $-0.176^{* *}$ & 0.0396 & 0.0162 \\
\hline & & $(0.100)$ & $(0.0778)$ & $(0.0672)$ & & $(0.0693)$ & $(0.0614)$ & $(0.0790)$ \\
\hline & Big & -0.153 & $-0.392 * * *$ & -0.0228 & & $-0.286^{* * *}$ & 0.0991 & 0.00923 \\
\hline & & $(0.103)$ & $(0.0906)$ & $(0.110)$ & & $(0.0927)$ & $(0.0996)$ & $(0.110)$ \\
\hline \multirow[t]{6}{*}{$\beta_{T E R M}$} & Small & $0.143^{*}$ & $0.189^{* * *}$ & $0.145^{* *}$ & \multirow[t]{6}{*}{$\beta_{D E F}$} & $0.412^{* *}$ & $0.216^{* *}$ & $0.395 * * *$ \\
\hline & & $(0.0850)$ & $(0.0629)$ & $(0.0605)$ & & $(0.181)$ & $(0.102)$ & $(0.0931)$ \\
\hline & 2 & $0.201 * * *$ & $0.284^{* * *}$ & $0.233^{* * *}$ & & $0.399 * * *$ & $0.433^{* * *}$ & $0.222^{* *}$ \\
\hline & & $(0.0707)$ & $(0.0586)$ & $(0.0599)$ & & $(0.124)$ & $(0.103)$ & $(0.0882)$ \\
\hline & Big & 0.0629 & $0.220 * * *$ & $0.185^{* *}$ & & 0.0306 & $0.242^{*}$ & 0.273 \\
\hline & & $(0.0837)$ & $(0.0681)$ & $(0.0938)$ & & $(0.115)$ & $(0.126)$ & $(0.210)$ \\
\hline \multirow[t]{6}{*}{$\beta_{R E G}$} & Small & -0.247 & -0.00521 & -0.496 & \multirow[t]{6}{*}{$\alpha$} & 0.133 & $0.331^{* * *}$ & 0.197 \\
\hline & & $(0.472)$ & $(0.363)$ & $(0.389)$ & & $(0.147)$ & $(0.124)$ & $(0.155)$ \\
\hline & 2 & -0.170 & 0.215 & 0.0809 & & 0.118 & 0.0454 & 0.180 \\
\hline & & $(0.213)$ & $(0.245)$ & $(0.271)$ & & $(0.162)$ & $(0.137)$ & $(0.146)$ \\
\hline & Big & $0.622 * *$ & 0.350 & 0.359 & & 0.00296 & 0.0579 & 0.00543 \\
\hline & & $(0.292)$ & $(0.364)$ & $(0.369)$ & & $(0.168)$ & $(0.169)$ & $(0.209)$ \\
\hline \multirow[t]{3}{*}{ Adj. $R^{2}$} & Small & $51.8 \%$ & $49.2 \%$ & $57.9 \%$ & & & & \\
\hline & 2 & $59.3 \%$ & $55.8 \%$ & $57.3 \%$ & & & & \\
\hline & Big & $60.4 \%$ & $41.4 \%$ & $43.3 \%$ & & & & \\
\hline \multirow{3}{*}{\multicolumn{9}{|c|}{$\begin{array}{l}\text { GRS test statistic } \\
=1.03 \\
\mathrm{p}(\mathrm{GRS})=0.412\end{array}$}} \\
\hline & & & & & & & & \\
\hline & & & & & & & & \\
\hline \multicolumn{9}{|c|}{$\begin{array}{l}\text { This table reports factor loadings on the market factor (RM-Rf), the size factor (SMB), the value factor (HML), the momentum } \\
\text { factor (MOM), the leverage factor (LEV), the cash flow volatility factor (CFVOLA), the investment factor (INV), and the two } \\
\text { bond factors, i.e., the term structure factor (TERM) and the default factor (DEF), for nine portfolios sorted by size (ME) and } \\
\text { book-to-market equity (BE/ME). The sample period is January } 1980 \text { to December } 2011 \text { ( } 384 \text { monthly observations). The GRS } \\
\text { test statistics and adjusted } R^{2} \text { values from each time series are reported at the end of the table. Standard errors are reported } \\
\text { in parentheses and are computed using the Newey-West (1987) correction for heteroscedasticity and serial correlation. *, **, } \\
\text { and } * * * \text { denote statistical significance at the } 10 \%, 5 \% \text {, and } 1 \% \text { levels, respectively. }\end{array}$} \\
\hline
\end{tabular}

Looking at the infrastructure 10-factor model in Table 9 , the inclusion of additional factors improves the explanatory power in excess of the Fama/French model up to $18.7 \%$ in case of the medium size/medium book-to-market portfolio (from $40.3 \%$ to $59.0 \%$ ). The large additional power that the model is able to add in some portfolios emphasizes the need to consider additional factors in the case of infrastructure stocks so as to capture their specific characteristics. The GRS test statistic shows an extremely low value of 0.59 , indicating that the model is well specified. 
Regarding the individual factors, we find a significant and positive size premium for the smallest companies and a negative one for larger firms, showing that the SMB factor is a good proxy for size and confirming the size effect in infrastructure firms. Moreover, we document a positive leverage premium in all but the growth (i.e., low book-to-market) portfolios. Given that infrastructure firms in the growth portfolios have a reduced risk of being distressed (Daniel and Titman (1997)), one might conclude that investors do not receive a leverage premium for such companies.

In contrast to the regressions in Table 5, we now find a negative relationship between returns and INV in the case of low book-to-market portfolios. This contradicts the results found by Chen, Novy-Marx, and Zhang (2011) and Ammann, Odoni, and Oesch (2012) with respect to overall stocks in the U.S. and European markets. First, their results indicate a positive relation between the investment factor and the cross-section of stock returns. Second, the investment factor should enhance the explanatory power of the return variation for all portfolios. One explanation for the negative factor loading in our model could be that infrastructure companies with low book-to-market ratios (i.e., infrastructure firms with more growth opportunities than other infrastructure firms) are considered as sustainable firms that are willing to invest and for which investors are willing to pay higher prices today. ${ }^{19}$

\footnotetext{
${ }^{19}$ Note that the INV factor is constructed as low investments minus high investments. Thus a negative coefficient means that companies making investments receive a positive premium from investors.
} 
Table 9: Infrastructure asset class factor model from time series regressions: $R_{i, t}-R_{f, t}=$ $\alpha_{i}+\beta_{i, M}\left(R_{M, t}-R_{f, t}\right)+\beta_{i, S M B} S M B_{t}+\beta_{i, H M L} H M L_{t}+\beta_{i, M O M} M O M_{t}+\beta_{i, C F V O L A} C F V O L A_{t}+$ $\beta_{i, L E V} L E V_{t}+\beta_{i, I N V} I N V_{t}+\beta_{i, T E R M T E R M_{t}}+\beta_{i, D E F} D E F_{t}+\beta_{i, R E G} R E G_{t}+\epsilon_{i, t}$

\begin{tabular}{|c|c|c|c|c|c|c|c|c|}
\hline Variables & & Low & 2 & High & & Low & 2 & High \\
\hline \multirow[t]{5}{*}{$\beta_{M}$} & Small & $\begin{array}{l}0.740^{* * *} \\
(0.0540)\end{array}$ & $\begin{array}{l}0.550^{* * *} \\
(0.0329)\end{array}$ & $\begin{array}{l}0.731^{* * *} \\
(0.0402)\end{array}$ & \multirow[t]{5}{*}{$\beta_{S M B}$} & $\begin{array}{l}0.364^{* * *} \\
(0.0670)\end{array}$ & $\begin{array}{l}0.155^{* *} \\
(0.0610)\end{array}$ & $\begin{array}{l}0.265 * * * \\
(0.0582)\end{array}$ \\
\hline & 2 & $0.741^{* * *}$ & $0.583^{* * *}$ & $0.711^{* * *}$ & & 0.0333 & -0.00707 & $-0.140 * *$ \\
\hline & & $(0.0365)$ & $(0.0449)$ & $(0.0370)$ & & $(0.0820)$ & $(0.0804)$ & $(0.0586)$ \\
\hline & Big & $0.846^{* * *}$ & $0.604^{* * *}$ & $0.653^{* * *}$ & & $-0.244^{* * *}$ & $-0.222^{* * *}$ & $-0.237 * * *$ \\
\hline & & $(0.0534)$ & $(0.0481)$ & $(0.0530)$ & & $(0.0798)$ & $(0.0716)$ & $(0.0761)$ \\
\hline \multirow[t]{6}{*}{$\beta_{H M L}$} & Small & $0.466^{* * *}$ & $0.387^{* * *}$ & $0.374^{* * *}$ & \multirow[t]{6}{*}{$\beta_{M O M}$} & 0.0736 & $0.0906^{* * *}$ & 0.0369 \\
\hline & & $(0.110)$ & $(0.0657)$ & $(0.0582)$ & & $(0.0702)$ & $(0.0330)$ & $(0.0449)$ \\
\hline & 2 & $0.210^{* *}$ & $0.282^{* * *}$ & $0.351^{* * *}$ & & -0.0209 & $0.0775^{*}$ & $0.0710^{* *}$ \\
\hline & & $(0.0883)$ & $(0.0679)$ & $(0.0651)$ & & $(0.0492)$ & $(0.0395)$ & $(0.0337)$ \\
\hline & Big & -0.121 & $0.368 * * *$ & $0.302^{* * *}$ & & 0.0481 & 0.0584 & 0.0390 \\
\hline & & $(0.0800)$ & $(0.0881)$ & $(0.0967)$ & & $(0.0516)$ & $(0.0611)$ & $(0.0462)$ \\
\hline \multirow[t]{6}{*}{$\beta_{L E V}$} & Small & -0.0914 & $0.230^{* * *}$ & $0.538^{* * *}$ & \multirow[t]{6}{*}{$\beta_{C F V O L A}$} & -0.0311 & $-0.134^{* *}$ & $-0.173 * * *$ \\
\hline & & $(0.0854)$ & $(0.0553)$ & $(0.0635)$ & & $(0.0828)$ & $(0.0562)$ & $(0.0581)$ \\
\hline & 2 & -0.0485 & $0.489 * * *$ & $0.454^{* * *}$ & & $-0.332^{* * *}$ & $-0.190 * * *$ & -0.0771 \\
\hline & & $(0.0713)$ & $(0.0664)$ & $(0.0676)$ & & $(0.102)$ & $(0.0723)$ & $(0.0678)$ \\
\hline & Big & -0.00140 & $0.359 * * *$ & $0.414^{* * *}$ & & -0.0915 & $-0.241 * * *$ & 0.116 \\
\hline & & $(0.103)$ & $(0.0820)$ & $(0.0894)$ & & $(0.110)$ & $(0.0873)$ & $(0.113)$ \\
\hline \multirow[t]{6}{*}{$\beta_{I N V}$} & Small & $-0.248^{* * *}$ & -0.0425 & 0.0645 & \multirow[t]{6}{*}{$\beta_{T E R M}$} & $0.124^{*}$ & $0.176^{* * *}$ & $0.128^{* *}$ \\
\hline & & $(0.0938)$ & $(0.0583)$ & $(0.0706)$ & & $(0.0737)$ & $(0.0605)$ & $(0.0590)$ \\
\hline & 2 & $-0.172^{* *}$ & 0.0226 & -0.00758 & & $0.191^{* * *}$ & $0.277^{* * *}$ & $0.224 * * *$ \\
\hline & & $(0.0688)$ & $(0.0613)$ & $(0.0708)$ & & $(0.0731)$ & $(0.0616)$ & $(0.0563)$ \\
\hline & Big & $-0.306 * * *$ & 0.0729 & -0.0137 & & 0.0739 & $0.210^{* * *}$ & $0.176^{* *}$ \\
\hline & & $(0.0944)$ & $(0.0967)$ & $(0.112)$ & & $(0.0793)$ & $(0.0626)$ & $(0.0868)$ \\
\hline \multirow[t]{6}{*}{$\beta_{D E F}$} & Small & 0.232 & 0.117 & $0.244^{* * *}$ & \multirow[t]{6}{*}{$\beta_{R E G}$} & 0.262 & 0.308 & -0.112 \\
\hline & & $(0.175)$ & $(0.106)$ & $(0.0925)$ & & $(0.432)$ & $(0.286)$ & $(0.306)$ \\
\hline & 2 & $0.316^{* *}$ & $0.395 * * *$ & $0.191^{*}$ & & -0.0480 & 0.352 & 0.146 \\
\hline & & $(0.146)$ & $(0.0976)$ & $(0.101)$ & & $(0.222)$ & $(0.226)$ & $(0.214)$ \\
\hline & Big & 0.151 & $0.217^{*}$ & 0.259 & & 0.384 & 0.359 & 0.323 \\
\hline & & $(0.121)$ & $(0.117)$ & $(0.197)$ & & $(0.299)$ & $(0.307)$ & $(0.331)$ \\
\hline \multirow[t]{6}{*}{$\alpha$} & Small & -0.0754 & 0.153 & 0.0487 & \multirow[t]{6}{*}{ Adj. $R^{2}$} & $59.0 \%$ & $57.2 \%$ & $63.1 \%$ \\
\hline & & $(0.151)$ & $(0.113)$ & $(0.143)$ & & & & \\
\hline & 2 & 0.0769 & -0.0799 & 0.0570 & & $60.4 \%$ & $59.0 \%$ & $63.6 \%$ \\
\hline & & $(0.163)$ & $(0.131)$ & $(0.134)$ & & & & \\
\hline & Big & 0.0245 & -0.0520 & -0.0724 & & $61.9 \%$ & $49.7 \%$ & $49.2 \%$ \\
\hline & & $(0.171)$ & $(0.154)$ & $(0.207)$ & & & & \\
\hline
\end{tabular}

GRS test statistic

$=0.59$

$\mathrm{p}(\mathrm{GRS})=0.807$

This table reports factor loadings on the market factor (RM-RF), the size factor (SMB), the value factor (HML), the momentum factor (MOM), the leverage factor (LEV), the cash flow volatility factor (CFVOLA), the investment factor (INV), and the two bond factors, i.e., the term structure factor (TERM) and the default factor (DEF), for nine portfolios sorted by size (ME) and book-to-market equity (BE/ME). The sample period is January 1980 to December 2011 (384 monthly observations). The GRS test statistics and adjusted $R^{2}$ values from each time series are reported at the end of the table. Standard errors are reported in parentheses and are computed using the Newey-West (1987) correction for heteroscedasticity and serial correlation. *, **, and $* * *$ denote statistical significance at the $10 \%, 5 \%$, and $1 \%$ levels, respectively.

The factor loadings for the interest rate factors, TERM and DEF, remain positive and significant for 
all portfolios, corroborating the idea that infrastructure firms are sensitive to changes in interest rates. Possibly this is a consequence of the high leverage in combination with the long duration of investments by infrastructure firms. However, there is no clear evidence of larger companies being more interest rate sensitive than smaller ones, as O'Neal (1998) found to be the case for electric utility companies. The regulatory premium does not exhibit any significant result, which suggests that regulatory risk is not priced in the returns of infrastructure firms. Finally, we observe that cash flow volatility has a negative and significant effect in five of the nine portfolios. To some extent this corroborates the finding that infrastructure firms with stable cash flows are able to generate higher returns.

\subsection{Further Tests}

To investigate the role of infrastructure-specific risk factors and further validate the results from the time series regressions we conduct nine other tests. These tests include subsector and subperiod analyses, Fama-MacBeth (1973) regression analyses, out-of-sample tests, the application of the infrastructure factor models to commercial infrastructure indices both with and without the GJR-GARCH approach (Glosten, Jagannathan, and Runkle (1993)), and a stepwise regression approach. The latter three tests are presented in the Appendix of the paper. Moreover, we also test the defensive characteristics (i.e. downside protection) of infrastructure investments and whether infrastructure serves as an inflation hedge. These are not included in the main models, because previous studies (Rödel and Rothballer (2012); Bird, Liem, and Thorp (2012)) showed that infrastructure firms neither consistently hedges inflation nor offers defensive characteristics. Our extensive dataset and our infrastructure-specific factor models help to refine previous results and investigate the abilities of infrastructure investments in more detail.

\subsubsection{Analysis of Subsectors (Utilities vs. Non-Utilities)}

The infrastructure sector comprises several subsectors, including utility, transport, and telecommunication companies. Since stocks for transportation firms are rather sparse in our sample ${ }^{20}$ we differentiate between utility and non-utility firms to analyze the performance of our infrastructure models for these two subsectors. The sample comprises a total of 396 stocks with 258 utility stocks and 138 non-utility stocks

\footnotetext{
${ }^{20}$ For example, our sample does not include any airports since the privatization of airports is not usual in the United States. Indeed, it was only recently that the first negotiations over privatization of the Chicago Midway International Airport occurred.
} 
(i.e. 16 transport firms and 122 telecommunication firms). ${ }^{21}$ Table 10 shows the time series regression for the utilities and non-utilities sector run through the Fama/French three-factor model, the Carhart four-factor model, the infrastructure seven-factor model, and the infrastructure 10-factor model.

Table 10: Time series regressions of subsectors (utilities vs. non-utilities)

\begin{tabular}{|c|c|c|c|c|c|c|c|c|}
\hline \multicolumn{5}{|c|}{ Utilities } & \multicolumn{4}{|c|}{ Non-Utilities } \\
\hline & (1) & (2) & (3) & (4) & (5) & (6) & (7) & (8) \\
\hline Variables & $\begin{array}{l}\text { FF 3- } \\
\text { factor } \\
\text { model }\end{array}$ & $\begin{array}{l}\text { Carhart } \\
\text { 4-factor } \\
\text { model }\end{array}$ & $\begin{array}{l}\text { Infrastructure } \\
7 \text {-factor } \\
\text { model }\end{array}$ & $\begin{array}{l}\text { Infrastructure } \\
\text { 10-factor } \\
\text { model }\end{array}$ & $\begin{array}{l}\text { FF 3- } \\
\text { factor } \\
\text { model }\end{array}$ & $\begin{array}{l}\text { Carhart } \\
\text { 4-factor } \\
\text { model }\end{array}$ & $\begin{array}{l}\text { Infrastructure } \\
7 \text {-factor } \\
\text { model }\end{array}$ & $\begin{array}{l}\text { Infrastructure } \\
\text { 10-factor } \\
\text { model } \\
\end{array}$ \\
\hline$\beta_{M}$ & $\begin{array}{l}0.625 * * * \\
(0.0432)\end{array}$ & $\begin{array}{l}0.648^{* * *} \\
(0.0433)\end{array}$ & $\begin{array}{l}0.597 * * * \\
(0.0386)\end{array}$ & $\begin{array}{l}0.650^{* * *} \\
(0.0379)\end{array}$ & $\begin{array}{l}1.095^{* * *} \\
(0.0401)\end{array}$ & $\begin{array}{l}1.077 * * * \\
(0.0426)\end{array}$ & $\begin{array}{l}1.023 * * * \\
(0.0465)\end{array}$ & $\begin{array}{l}1.010^{* * *} \\
(0.0505)\end{array}$ \\
\hline$\beta_{S M B}$ & $\begin{array}{l}-0.222^{* * *} \\
(0.0658)\end{array}$ & $\begin{array}{l}-0.229^{* * *} \\
(0.0631)\end{array}$ & & $\begin{array}{l}-0.178^{* * *} \\
(0.0683)\end{array}$ & $\begin{array}{l}-0.0368 \\
(0.0679)\end{array}$ & $\begin{array}{l}-0.0318 \\
(0.0673)\end{array}$ & & $\begin{array}{l}0.0105 \\
(0.0699)\end{array}$ \\
\hline$\beta_{H M L}$ & $\begin{array}{l}0.378^{* * *} \\
(0.0829)\end{array}$ & $\begin{array}{l}0.416^{* * *} \\
(0.0794)\end{array}$ & & $\begin{array}{l}0.231 * * * \\
(0.0711)\end{array}$ & $\begin{array}{l}-0.164 * * \\
(0.0737)\end{array}$ & $\begin{array}{l}-0.195^{* *} \\
(0.0820)\end{array}$ & & $\begin{array}{l}-0.0716 \\
(0.0695)\end{array}$ \\
\hline$\beta_{M O M}$ & & $\begin{array}{l}0.109 * * \\
(0.0492)\end{array}$ & & $\begin{array}{l}0.0952^{* *} \\
(0.0438)\end{array}$ & & $\begin{array}{l}-0.0878 \\
(0.0639)\end{array}$ & & $\begin{array}{l}-0.0781 \\
(0.0583)\end{array}$ \\
\hline$\beta_{C F V O L A}$ & & & $\begin{array}{l}-0.428^{* * *} \\
(0.0791)\end{array}$ & $\begin{array}{l}-0.309^{* * *} \\
(0.0805)\end{array}$ & & & $\begin{array}{l}-0.0207 \\
(0.0704)\end{array}$ & $\begin{array}{l}-0.0535 \\
(0.0657)\end{array}$ \\
\hline$\beta_{L E V}$ & & & $\begin{array}{l}0.514^{* * *} \\
(0.0706)\end{array}$ & $\begin{array}{l}0.405^{* * *} \\
(0.0714)\end{array}$ & & & $\begin{array}{l}-0.319^{* * *} \\
(0.0891)\end{array}$ & $\begin{array}{l}-0.292^{* * *} \\
(0.0739)\end{array}$ \\
\hline$\beta_{I N V}$ & & & $\begin{array}{l}-0.133^{*} \\
(0.0737)\end{array}$ & $\begin{array}{l}-0.162^{* *} \\
(0.0722)\end{array}$ & & & $\begin{array}{l}0.0841 \\
(0.0717)\end{array}$ & $\begin{array}{l}0.0992 \\
(0.0752)\end{array}$ \\
\hline$\beta_{T E R M}$ & & & $\begin{array}{l}0.216^{* * *} \\
(0.0552)\end{array}$ & $\begin{array}{l}0.214^{* * *} \\
(0.0525)\end{array}$ & & & $\begin{array}{l}0.00361 \\
(0.0664)\end{array}$ & $\begin{array}{l}0.00167 \\
(0.0648)\end{array}$ \\
\hline$\beta_{D E F}$ & & & $\begin{array}{l}0.249^{* *} \\
(0.103)\end{array}$ & $\begin{array}{l}0.277^{* * *} \\
(0.104)\end{array}$ & & & $\begin{array}{l}0.132 \\
(0.122)\end{array}$ & $\begin{array}{l}0.104 \\
(0.111)\end{array}$ \\
\hline$\beta_{R E G}$ & & & $\begin{array}{l}0.113 \\
(0.251)\end{array}$ & $\begin{array}{l}0.0969 \\
(0.212)\end{array}$ & & & $\begin{array}{l}0.783^{* *} \\
(0.335)\end{array}$ & $\begin{array}{l}0.747 * * \\
(0.335)\end{array}$ \\
\hline$\alpha$ & $\begin{array}{l}0.119 \\
(0.157)\end{array}$ & $\begin{array}{l}0.0247 \\
(0.164)\end{array}$ & $\begin{array}{l}0.00598 \\
(0.133)\end{array}$ & $\begin{array}{l}-0.101 \\
(0.127)\end{array}$ & $\begin{array}{l}0.0640 \\
(0.173)\end{array}$ & $\begin{array}{l}0.140 \\
(0.186)\end{array}$ & $\begin{array}{l}0.125 \\
(0.154)\end{array}$ & $\begin{array}{l}0.198 \\
(0.169)\end{array}$ \\
\hline $\begin{array}{l}\text { Monthly obs. } \\
\text { Adj. } R^{2}\end{array}$ & $\begin{array}{l}384 \\
46.4 \%\end{array}$ & $\begin{array}{l}384 \\
47.7 \%\end{array}$ & $\begin{array}{l}384 \\
56.4 \%\end{array}$ & $\begin{array}{l}384 \\
61.1 \%\end{array}$ & $\begin{array}{l}384 \\
75.2 \%\end{array}$ & $\begin{array}{l}384 \\
75.5 \%\end{array}$ & $\begin{array}{l}384 \\
77.2 \%\end{array}$ & $\begin{array}{l}384 \\
77.4 \%\end{array}$ \\
\hline
\end{tabular}

This table reports factor loadings from time series regressions for the Fama/French three-factor model (Columns 1 and 5 ), the Carhart four-factor model (Columns 2 and 6), the infrastructure seven-factor model (Columns 3 and 7 ), and the infrastructure 10 -factor model as an augmented version of the Carhart four-factor model (Columns 4 and 8). The dependent variable in Columns 1 to 4 is a value-weighted index of all utility stocks. The dependent variable in Columns 5 to 8 is a value-weighted index of all non-utility stocks (telecommunication and transport). The sample period is January 1980 to December 2011 (384 monthly observations). The adjusted $R^{2}$ values from each time series are reported at the end of the table. Standard errors are reported in parentheses and are computed using the Newey-West (1987) correction for heteroscedasticity and serial correlation. $*, * *$, and $* * *$ denote statistical significance at the $10 \%, 5 \%$, and $1 \%$ levels, respectively.

For the utility sector, the results of the time series regressions are very consistent with the main results presented in Table 5. It thus seems that the infrastructure model is especially eligible for the utility sector, which according to our data is the largest infrastructure sector, both in terms of the number of stocks as well as in terms of market volume. For the non-utility sector, we observe a much larger market exposure with beta values between 1.0 and 1.1. These results are consistent with previous findings by Rothballer

\footnotetext{
${ }^{21}$ We also run time-series regressions for telecommunication firms only. Results are virtually identical to the non-utility regression results presented in Table 10 except for the investment factor which is significant and positive at the $5 \%$ level for telecommunication firms.
} 
and Kaserer (2012), who show, in a global market perspective, beta values between 0.9 and 1.1 for telecommunication firms and between 0.6 and 0.8 for transportation firms. For the non-utility firms, we also observe that the HML factor is significant and negative in the Fama/French three-factor and Carhart four factor model, but the significance disappears in the 10-factor model and seems to be captured by the leverage factor. This implies that non-utility firms (i.e. in our sample especially telecommunication firms) are more affected by their leverage ratios rather than by their book-to-market ratios despite the fact that telecommunication firms are usually considered growth firms. Moreover, the regulatory factor has a positive impact on non-utility returns, suggesting that investors receive compensation for their capped returns. The finding that the utility and non-utility infrastructure sectors are not completely homogeneous confirms the findings by Bird, Liem, and Thorp (2012) who show that a potential inflation hedge only exists for the utility industry but not the infrastructure sector as whole. Despite the few significant factors explaining non-utility stocks, the market factor explains a large part in the variation, which results in R-squares between $75.2 \%$ for the Fama/French three-factor model and $77.4 \%$ for the infrastructure 10-factor model. For the utility stocks, we observe a strong increase in explanatory power from $46.4 \%$ for the Fama/French three-factor model to $56.4 \%$ for the infrastructure seven-factor model up to $61.1 \%$ for the infrastructure 10 -factor model. We conclude that the infrastructure subsectors are rather heterogeneous and that the explanatory power of standard pricing models can be improved by infrastructure-specific factors.

\subsubsection{Fama-MacBeth Regressions}

Results from time series regressions suggest that infrastructure-specific variables (i.e., those variables used in the seven-factor model) are superior in explaining variation of infrastructure returns compared to the Fama/French three-factor or the Carhart four-factor models. However, these results do not necessarily indicate whether our model performs better or worse in a cross-sectional analysis. To determine if the six infrastructure factors are important in conjunction with the Carhart factors (RM-Rf, SMB, HML, and MOM), we run Fama-MacBeth (1973) regressions for each model. Due to the low number of test assets (i.e., nine test portfolios), we use excess returns of individual stocks as the dependent variable since individual stocks as test assets are more reliable in finding risk premium according to Ang, Liu, and Schwarz (2010). From a first-pass time series regression of the excess returns on a constant, $\left(R_{M, t}-R_{f, t}\right), S M B_{t}, H M L_{t}, M O M_{t}, C F V O L A_{t}, L E V_{t}, I N V_{t}, T E R M_{t}, D E F_{t}$, and $R E G_{t}$ we obtain 
the slope coefficients for the infrastructure ten-factor model. The second stage consists of cross-sectional regressions for each month, where the dependent variable is the mean excess return (over the sample period) of the 396 stocks (i.e., 258 utility stocks and 138 non-utility stocks in the infrastructure sector) and the independent variables are the slope coefficients from the first stage regression. Because the slope coefficients are estimated parameters from first-pass time series regressions, the classical errors-invariables problem in second-pass cross-section regressions arises. We follow Shanken (1992) in correcting for the errors-in-variables issue. The R-squares of the regressions are adjusted following Jagannathan and Wang (1996). For the infrastructure 10-factor model, the regression is formally defined as:

$$
\begin{aligned}
R_{i, t}-R_{f, t} & =\gamma_{0}+\gamma_{M} \hat{\beta}_{i, M}+\gamma_{S M B} \hat{\beta}_{i, S M B}+\gamma_{H M L} \hat{\beta}_{i, H M L}+ \\
& \gamma_{M O M} \hat{\beta}_{i, M O M}+\gamma_{C F V O L A} \hat{\beta}_{i, C F V O L A}+\gamma_{L E V} \hat{\beta}_{i, L E V}+\gamma_{I N V} \hat{\beta}_{i, I N V}+ \\
& \gamma_{T E R M} \hat{\beta}_{i, T E R M}+\gamma_{D E F} \hat{\beta}_{i, D E F}+\gamma_{R E G} \hat{\beta}_{i, R E G}+\epsilon_{i, t} .
\end{aligned}
$$

The CAPM, the Fama/French three-factor, the Carhart four-factor, and the infrastructure sevenfactor model follow the same logic of regression. Our main interest is whether the average coefficient slopes on the six infrastructure factor loadings (or seven factor loadings with the market beta) are significantly positive or negative and thus important determinants of infrastructure returns in the presence of the Carhart factors. Regression results are shown in Table 11. With respect to the regression results for all stocks, we merely note that both the infrastructure seven- and ten-factor models reduce the significance of the intercept. None of the remainder of the regressions reveal any significant results. One potential explanation for the insignificant results is that there is too much idiosyncratic variation in and not enough of individual stocks to draw a clear picture.

\subsubsection{Analysis of Defensive Characteristics}

Based on our asset class factor model from Equation (4) and a squared market factor as in Treynor and Mazuy (1966), we also analyze the defensive characteristics of our nine test portfolios to market movements. The assumption is that certain portfolios with higher book-to-market ratios or larger market capitalization perform differently during economic downturns.

Thus, our work goes beyond the previous analysis of Bird, Liem, and Thorp (2012), who analyze the 


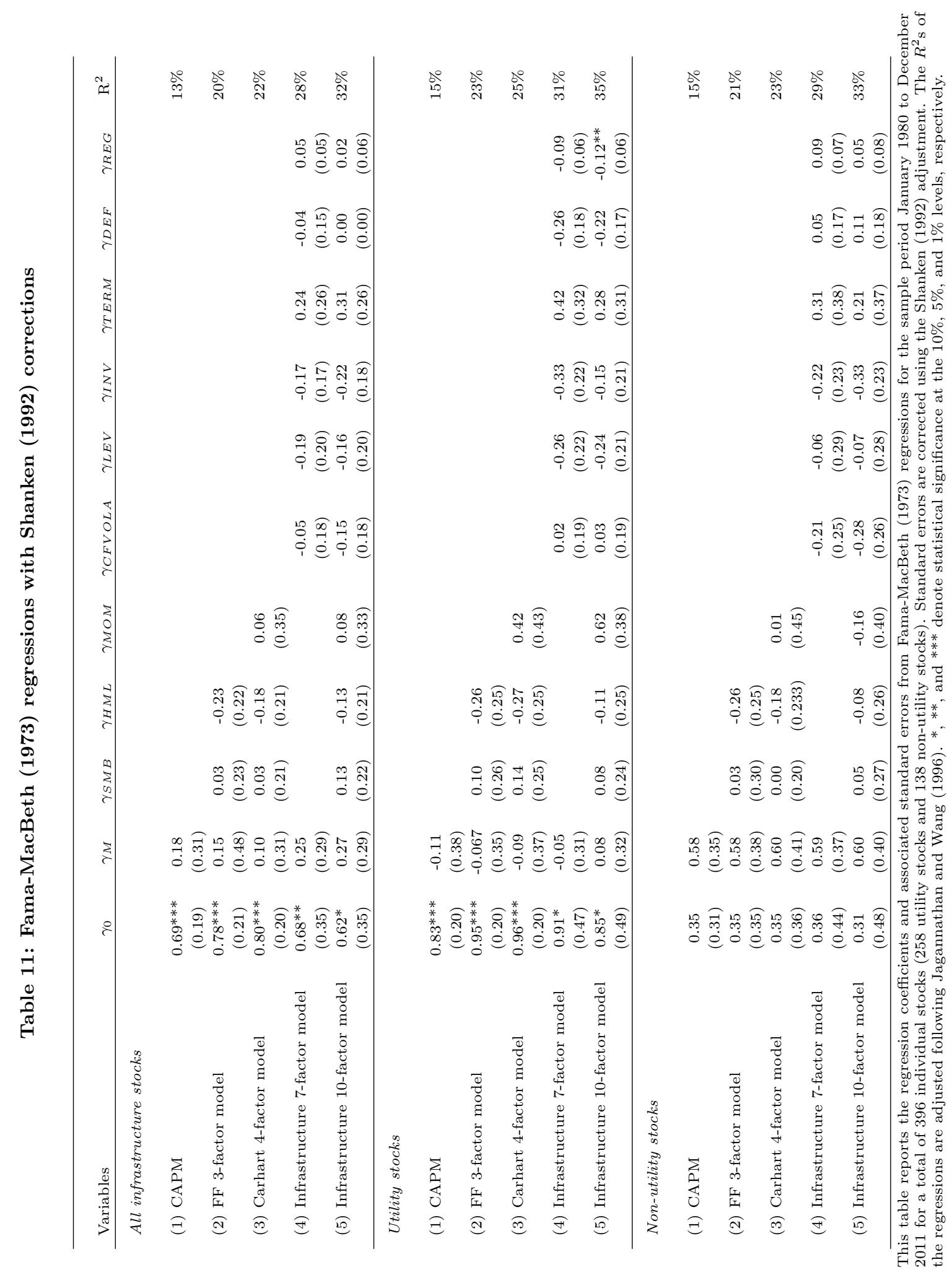


U.S. and Australian markets, but cannot differentiate their indices by size or book-to-market characteristics. Figure 1 illustrates the predicted infrastructure returns from Equation (4), with the squared market excess return on the vertical axis and the market excess return on the horizontal axis. A convex relation (demonstrated by the solid red line) between predicted infrastructure returns and market excess returns would indicate that an increasingly severe market plunge has a decreasingly severe effect on the infrastructure firms.

Figure 1 shows that all but one of the nine portfolios experience a concave, linear, or insignificantly convex relation between predicted infrastructure returns and the market excess return. Only portfolio $3 / 2$ (i.e., the large market capitalization/medium book-to-market ratio portfolio) shows a significant convex relation between infrastructure and market returns. This result seems odd, given that all other large size portfolios have linear or concave relations, as do the medium book-to-market ratio portfolios. The low fit for portfolio $3 / 2$ (an adjusted R-square of $50.5 \%$ ) suggests that there are other and as yet unknown factors that, if they could be discovered and integrated into the model, might result in a more consistent picture of the defensive nature of infrastructure returns. Overall, our results confirm the findings of Bird, Liem, and Thorp (2012) that infrastructure firms do not behave defensively during economic downturns. ${ }^{22}$

\footnotetext{
${ }^{22}$ We also use a dummy variable for up and down markets ( 1 for up and 0 for down) to control for the defensive characteristics. Results are virtually identical and show no significant effects on the dummy variable.
} 


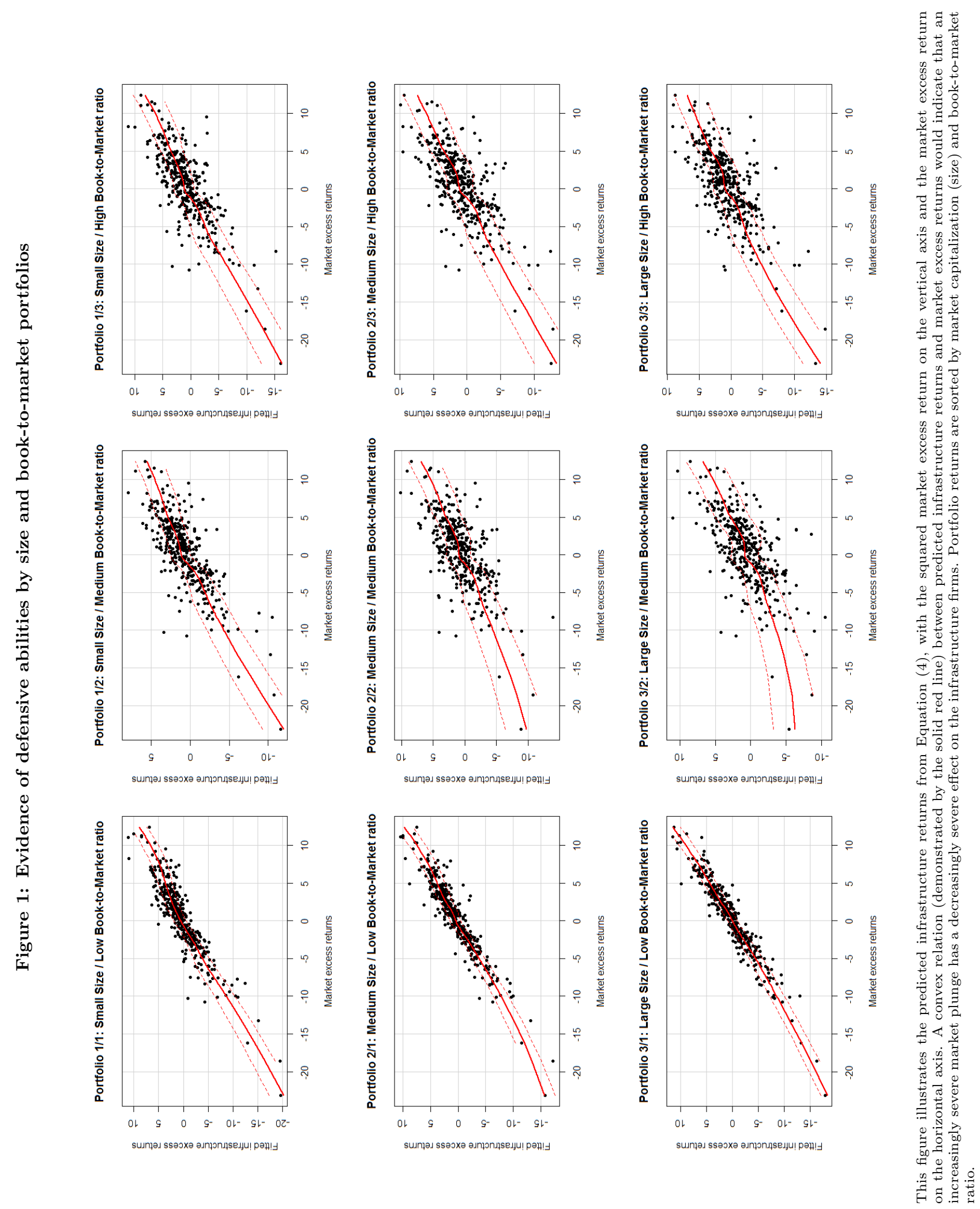




\subsubsection{Analysis of Inflation Hedge}

We further investigate the assumption that infrastructure is a potential hedge against inflation. This popular assumption among practitioners has been rejected by Rödel and Rothballer (2012) and is only weakly confirmed by Bird, Liem, and Thorp (2012) for utility stocks. To shed more light on these mixed results, we control for an inflation hedge ability of infrastructure firms in our model by including the total return of Treasury Inflation Protected Securities (TIPS) minus the risk-free rate. Our dataset allows us to differentiate both between industry sectors, size and book-to-market ratio, respectively. However, the TIPS return series only begins in February 1997 and hence covers less than half our entire sample period. We use the total return series of the Barclays US TIPS index, which aggregates all maturities to investigate the inflation hedging abilities of infrastructure returns. Subtracting the risk-free return from monthly TIPS series results in an excess return series for our inflation factor (INFL). In contrast to the Consumer Price Index (CPI), TIPS are tradable and, thus, represent investment returns, allowing us to directly determine the risk premium of inflation which is $0.35 \%$ per month. Given the close relation between inflation, term structure, default probability, and regulatory premium (i.e., they are all based on interest rates), we first note that the inflation factor, INFL, is highly correlated with the TERM factor $(\rho=0.5)$. As mentioned above (see section 2.4) this result is in line with Ang, Bekaert, and Wei (2008) who point out the relation between term structure and inflation. Regressing INFL on all other previously introduced dependent variables reveals that INFL is also highly dependent on the default factor, DEF, and to some extent on CFVOLA and REG. Equation (7) shows coefficient estimates with t-statistics in parentheses using Newey-West (1987) corrected standard errors with three lags:

$$
\begin{aligned}
& \mathrm{INFL}=0.18-0.01(\mathrm{RM}-\mathrm{Rf})-0.05 \mathrm{SMB}+0.05 \mathrm{HML}+0.00 \mathrm{MOM}+0.11 \mathrm{CFVOLA}- \\
& \begin{array}{lllll}
(1.54) \quad(-0.30) \quad(-1.60) & (0.95) \quad(0.32) \quad(1.95)
\end{array} \\
& 0.05 \mathrm{LEV}-0.06 \mathrm{INV}+0.32 \mathrm{TERM}+0.23 \mathrm{DEF}-1.30 \mathrm{REG} . \\
& \begin{array}{llll}
(-1.11) \quad(1.53) \quad(6.81) \quad(2.14) \quad(-1.85)
\end{array}
\end{aligned}
$$

The adjusted R-square of this regression is $36.1 \%$. Based on this regression, we construct an orthogonalized inflation factor as the sum of the intercept and the residuals to eliminate multicollinearity issues. This factor can be interpreted as a zero-investment portfolio that is uncorrelated with all other factors. 
Table 12 shows the regression estimates for the inflation factor. Panel A of Table 12 runs different model specifications with the VWI index as dependent variable. Inflation is not significant in any of the model specifications, corroborating the results of Rödel and Rothballer (2012). Panel B demonstrates that infrastructure can hedge inflation in case of smaller growth firms. The majority of portfolios, however, does not hedge against inflation. A possible explanation why smaller growth firms are able to protect against inflation, at least to some extent, is their ability to adjust price changes faster than their larger and more complex competitors. Also their local focus could prevent them from confrontations with larger competitors in several areas at the same time, which would make them more vulnerable to pricing competitions despite the regulatory framework. Panel C looks at the inflation hedge of utility and non-utility stocks within the infrastructure sector, finding a weak inflation hedge ability of utility stocks whereas non-utility stocks cannot hedge inflation. Overall our results confirm the results of Rödel and Rothballer (2012) and Bird, Liem, and Thorp (2012) that infrastructure firms do not guarantee inflation protection. Only minor evidence suggests that utility firms and smaller growth firms are able to hedge inflation to some extent. 
Table 12: Inflation hedge abilities of infrastructure firms

Panel A: Value-weighted infrastructure index as dependent variable

\begin{tabular}{|c|c|c|c|c|c|}
\hline & (1) & $(2)$ & (3) & $(4)$ & (5) \\
\hline Variables & CAPM & FF 3-factor model & Carhart 4-factor model & $\begin{array}{l}\text { Infrastructure } \\
7 \text {-factor model }\end{array}$ & $\begin{array}{l}\text { Infrastructure } \\
10 \text {-factor model }\end{array}$ \\
\hline$\beta_{I N F L \perp}$ & $\begin{array}{c}0.104 \\
(0.112)\end{array}$ & $\begin{array}{c}0.104 \\
(0.113)\end{array}$ & $\begin{array}{c}0.104 \\
(0.112)\end{array}$ & $\begin{array}{l}0.104 \\
(0.105)\end{array}$ & $\begin{array}{l}0.104 \\
(0.101)\end{array}$ \\
\hline$\alpha$ & $\begin{array}{c}0.0481 \\
(0.199)\end{array}$ & $\begin{array}{c}0.0656 \\
(0.191)\end{array}$ & $\begin{array}{l}0.0420 \\
(0.194)\end{array}$ & $\begin{array}{l}0.0197 \\
(0.181)\end{array}$ & $\begin{array}{l}0.0170 \\
(0.178)\end{array}$ \\
\hline $\begin{array}{l}\text { Monthly obs. } \\
\text { Adj. } \mathrm{R}^{2}\end{array}$ & $\begin{array}{c}179 \\
68.0 \%\end{array}$ & $\begin{array}{c}179 \\
68.9 \%\end{array}$ & $\begin{array}{c}179 \\
69.0 \%\end{array}$ & $\begin{array}{l}179 \\
73.9 \%\end{array}$ & $\begin{array}{l}179 \\
74.0 \%\end{array}$ \\
\hline
\end{tabular}

Panel B: Inflation and infrastructure returns sorted by size and book-to-market ratio

\begin{tabular}{|c|c|c|c|c|c|c|c|c|}
\hline Variables & & Low & 2 & High & & Low & 2 & High \\
\hline \multirow[t]{3}{*}{$\beta_{I N F L \perp}$} & Small & $\begin{array}{l}0.593^{* *} \\
(0.274)\end{array}$ & $\begin{array}{c}-0.0136 \\
(0.163)\end{array}$ & $\begin{array}{l}0.0225 \\
(0.213)\end{array}$ & Adj. $R^{2}$ & $55.6 \%$ & $55.3 \%$ & $62.7 \%$ \\
\hline & 2 & $\begin{array}{l}0.421^{* *} \\
(0.169)\end{array}$ & $\begin{array}{l}0.222 \\
(0.149)\end{array}$ & $\begin{array}{l}0.169 \\
(0.180)\end{array}$ & & $59.0 \%$ & $58.4 \%$ & $56.3 \%$ \\
\hline & Big & $\begin{array}{l}0.0650 \\
(0.252)\end{array}$ & $\begin{array}{l}0.159 \\
(0.178)\end{array}$ & $\begin{array}{l}0.315 \\
(0.353)\end{array}$ & & $54.7 \%$ & $43.6 \%$ & $40.5 \%$ \\
\hline
\end{tabular}

Panel C: Inflation and subsectors

\begin{tabular}{|c|c|c|c|c|c|c|c|c|}
\hline \multicolumn{5}{|c|}{ Utilities } & \multicolumn{4}{|c|}{ Non-Utilities } \\
\hline & (1) & (2) & (3) & (4) & (5) & (6) & (7) & (8) \\
\hline Variables & $\begin{array}{l}\text { FF 3- } \\
\text { factor } \\
\text { model }\end{array}$ & $\begin{array}{l}\text { Carhart } \\
\text { 4-factor } \\
\text { model }\end{array}$ & $\begin{array}{l}\text { Infrastructure } \\
7 \text {-factor } \\
\text { model }\end{array}$ & $\begin{array}{l}\text { Infrastructure } \\
10 \text {-factor } \\
\text { model }\end{array}$ & $\begin{array}{l}\text { FF 3- } \\
\text { factor } \\
\text { model }\end{array}$ & $\begin{array}{l}\text { Carhart } \\
4 \text {-factor } \\
\text { model }\end{array}$ & $\begin{array}{l}\text { Infrastructure } \\
7 \text {-factor } \\
\text { model }\end{array}$ & $\begin{array}{l}\text { Infrastructure } \\
10 \text {-factor } \\
\text { model }\end{array}$ \\
\hline$\beta_{I N F L \perp}$ & $\begin{array}{l}0.311^{*} \\
(0.179)\end{array}$ & $\begin{array}{l}0.311^{*} \\
(0.179)\end{array}$ & $\begin{array}{l}0.311^{*} \\
(0.176)\end{array}$ & $\begin{array}{l}0.311^{*} \\
(0.160)\end{array}$ & $\begin{array}{c}-0.0601 \\
(0.178)\end{array}$ & $\begin{array}{c}-0.0601 \\
(0.187)\end{array}$ & $\begin{array}{c}-0.0601 \\
(0.150)\end{array}$ & $\begin{array}{c}-0.0601 \\
(0.157)\end{array}$ \\
\hline$\alpha$ & $\begin{array}{l}0.167 \\
(0.273)\end{array}$ & $\begin{array}{l}0.115 \\
(0.280)\end{array}$ & $\begin{array}{l}-0.00512 \\
(0.238)\end{array}$ & $\begin{array}{c}-0.0546 \\
(0.218)\end{array}$ & $\begin{array}{c}-0.0924 \\
(0.282)\end{array}$ & $\begin{array}{c}-0.0199 \\
(0.291)\end{array}$ & $\begin{array}{l}0.221 \\
(0.256)\end{array}$ & $\begin{array}{l}0.291 \\
(0.275)\end{array}$ \\
\hline Monthly obs. & 179 & 179 & 179 & 179 & 179 & 179 & 179 & 179 \\
\hline Adj. $\mathrm{R}^{2}$ & $37.7 \%$ & $38.4 \%$ & $51.0 \%$ & $53.7 \%$ & $74.6 \%$ & $75.3 \%$ & $77.2 \%$ & $77.7 \%$ \\
\hline
\end{tabular}

This table reports regression results for the inflation factor. The inflation factor (INFL) is the orthogonalized excess return of the TIPS return series over the 1-month T-bill rate. Panel A shows regression results for the value-weighted infrastructure index as dependent variable. Panel B shows factor loadings of INFL extracted from infrastructure 10-factor model regressions where the dependent variables are portfolio excess returns sorted by size and book-to-market ratio. Adjusted $R^{2}$ s are also reported for these regressions. Panel $\mathrm{C}$ shows factor loadings of INFL for the Fama/French three-factor model (Columns 1 and 5 ), the Carhart four-factor model (Columns 2 and 6), the infrastructure seven-factor model (Columns 3 and 7), and the infrastructure

10-factor model (Columns 4 and 8). The dependent variable in Columns 1 to 4 is a value-weighted index of all utility stocks. The dependent variable in Columns 5 to 8 is a value-weighted index of all non-utility stocks (telecommunication and transport). The sample period in Panel A, B, and C is February 1997 to December 2011 (179 monthly observations). Standard errors are reported in parentheses and are computed using the Newey-West (1987) correction for heteroscedasticity and serial correlation. $*, * *$, and $* * *$ denote statistical significance at the $10 \%, 5 \%$, and $1 \%$ levels, respectively. 


\subsubsection{Analysis of Subperiods}

We divide the data into three equal subperiods of 128 months each. Table 13 reports the regression results for the three different subperiods between January 1980 and December 2011.

The infrastructure seven-factor model documents a higher explanatory power for all three periods compared to the Fama/French three-factor model. The biggest difference between the two models occurs in the most recent period where the infrastructure seven-factor model explains $5.1 \%$ more in the time series variation of infrastructure returns than the Fama/French three-factor model. The smallest difference occurs during the time span of 1980 to 1990 where the adjusted R-square increases by $2.0 \%$. The market beta, cash flow volatility, and term premium are the only factors that consistently explain the return variation through all three time periods. That the Fama/French factors and the constructed infrastructure factors do not explain the variation during all time periods suggests that infrastructure returns are not exposed to the same risk factors at all times, but are subject to time-varying risk components (e.g., the size factor is more relevant during distressed times than during economically stable times).

However, we also ran all three models excluding the financial crisis of 2008/2009 in order to analyze whether this event significantly impacts our estimation result. The results were virtually identical to the results in Table 5 .

\subsubsection{Out-of-sample tests}

Due to the large number of factors both in the infrastructure 7 -factor model and, especially, in the 10-factor model, overfitting might be a concern. We address this issue with out-of-sample tests. Our approach follows, for the most part, Fama and French (1997) by determining slope coefficients from rolling regressions over the past 36 months and implementing them in one-month-, one-year-, three-year-, and five-year-ahead factor estimates. More precisely, the forecasts for each month $t+i$ (where $i$ is either 1 month, 1 year, 3 years or 5 years) are determined by slopes for months $t$ - 36 to $t$ from rolling regressions and the respective factors (depending on the model) for month $t+i$. Because of the different look-ahead periods the one-month-ahead estimates comprise monthly forecast errors from January 1985 to December 2011, the one-year-ahead estimates from December 1985 to December 2011, the threeyear-ahead estimates from December 1987 to December 2011, and the five-year-ahead estimates from December 1989 to December 2011. Our dependent variable is the value-weighted infrastructure index. Both the rolling regressions and the forecasts are determined without intercept. The difference between 


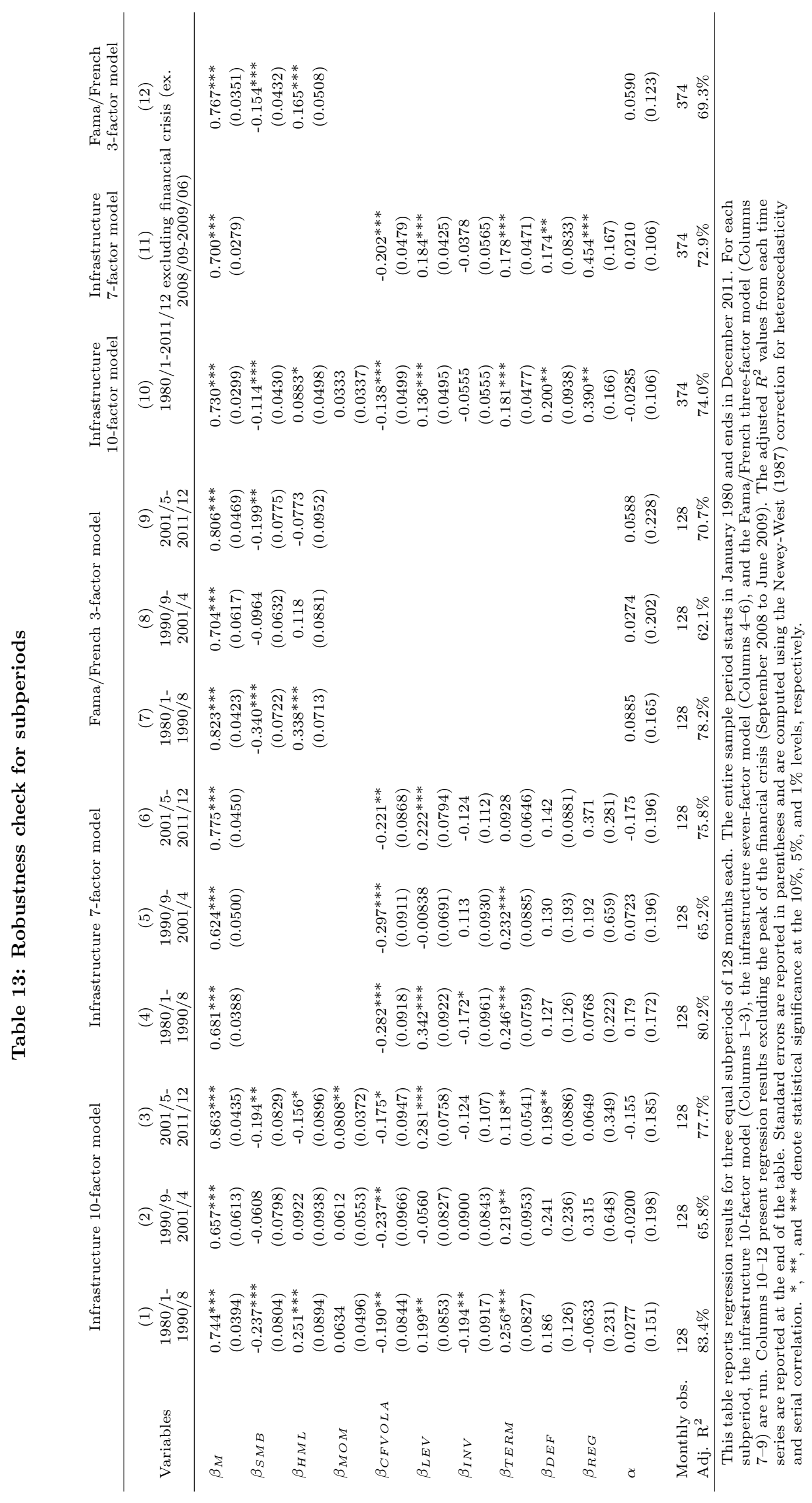


realized and predicted returns is the forecast error.

In Table 14 we present the mean of the forecast error over the predicting time period, the mean absolute value of the forecast error, and the standard deviation of the forecast error. The most striking result is the high predictive power of the infrastructure 7 -factor model with mean error values of almost $0 .^{23}$ Only the CAPM seems to have a slight advantage over the infrastructure seven-factor model in the five-year-ahead estimation. Depending on which indicator is looked at, neither the mean absolute error nor the mean standard error clearly reveal which model is superior.

Table 14: Prediction errors from out-of-sample tests

\begin{tabular}{|c|c|c|c|c|c|}
\hline Model & $\begin{array}{l}(1) \\
\text { CAPM }\end{array}$ & $\begin{array}{l}(2) \\
\text { FF 3-factor } \\
\text { model }\end{array}$ & $\begin{array}{l}(3) \\
\text { Carhart } \\
\text { 4-factor } \\
\text { model }\end{array}$ & $\begin{array}{l}(4) \\
\text { Infrastructure } \\
7 \text {-factor } \\
\text { model }\end{array}$ & $\begin{array}{l}(5) \\
\text { Infrastructure } \\
\text { 10-factor } \\
\text { model }\end{array}$ \\
\hline \multicolumn{6}{|l|}{1 month ahead } \\
\hline Mean error & $0.077 \%$ & $-0.038 \%$ & $-0.046 \%$ & $-0.015 \%$ & $-0.103 \%$ \\
\hline Mean absolute error & $1.821 \%$ & $1.719 \%$ & $1.717 \%$ & $1.737 \%$ & $1.701 \%$ \\
\hline Mean std error & $2.301 \%$ & $2.180 \%$ & $2.190 \%$ & $2.274 \%$ & $2.235 \%$ \\
\hline \multicolumn{6}{|l|}{12 month ahead } \\
\hline Mean error & $0.054 \%$ & $-0.057 \%$ & $-0.121 \%$ & $-0.022 \%$ & $-0.155 \%$ \\
\hline Mean absolute error & $1.819 \%$ & $1.798 \%$ & $1.890 \%$ & $1.899 \%$ & $2.091 \%$ \\
\hline Mean std error & $2.301 \%$ & $2.342 \%$ & $2.491 \%$ & $2.477 \%$ & $2.797 \%$ \\
\hline \multicolumn{6}{|l|}{36 month ahead } \\
\hline Mean error & $0.047 \%$ & $-0.104 \%$ & $-0.216 \%$ & $0.003 \%$ & $-0.151 \%$ \\
\hline Mean absolute error & $1.808 \%$ & $1.859 \%$ & $1.924 \%$ & $1.904 \%$ & $2.096 \%$ \\
\hline Mean std error & $2.287 \%$ & $2.438 \%$ & $2.588 \%$ & $2.458 \%$ & $2.915 \%$ \\
\hline \multicolumn{6}{|l|}{60 month ahead } \\
\hline Mean error & $0.014 \%$ & $-0.103 \%$ & $-0.197 \%$ & $-0.108 \%$ & $-0.238 \%$ \\
\hline Mean absolute error & $1.840 \%$ & $1.958 \%$ & $2.008 \%$ & $1.854 \%$ & $2.012 \%$ \\
\hline Mean std error & $2.308 \%$ & $2.528 \%$ & $2.631 \%$ & $2.435 \%$ & $2.651 \%$ \\
\hline
\end{tabular}

This table shows mean errors, mean absolute errors, and mean standard deviation of forecast errors from 36-month rolling regressions of the CAPM, the Fama/French three-factor, the Carhart four-factor, the infrastructure seven-factor, and the infrastructure ten-factor model. Forecast errors are estimated as realized returns minus predicted returns for each model. The forecasts span over a one-month-ahead, a one-year-ahead, a three-year-ahead, and a five-year-ahead estimate.

Regarding the infrastructure ten-factor model, concern about overfitting cannot be entirely eliminated given that this model shows the largest values in mean error terms and also the largest deviations of mean errors for most forecast periods. Even though the error terms and their deviations are small in

\footnotetext{
${ }^{23} \mathrm{~A}$ zero mean regarding the 7-factor infrastructure model is specifically relevant for regulators who need to know what the cost of equity is on average several years in advance as well as for project evaluations in the infrastructure sector.
} 
magnitude for the infrastructure ten-factor model, we can conclude that the infrastructure seven-factor model is superior to the ten-factor infrastructure model and outperforms the Fama/French three factor model in the long run which is especially relevant for infrastructure regulators who are less interested in one-month-ahead predictions but very interested in long-horizon estimates given the nature of long-term contracts in the infrastructure sector (see Gregory and Michou (2009)).

\section{Conclusion}

This paper identifies the common risk factors that are priced in infrastructure companies and constructs an asset class factor model. Established pricing models are tested, i.e., the single-factor CAPM, the Fama/French three-factor model, and the Carhart four-factor model. We create a seven-factor model and a 10-factor model, both of which are superior in explaining the return variation of infrastructure firms compared to the Fama/French three-factor model or the Carhart four-factor model. The sevenfactor model consists of the market excess return and six additional factors: cash flow volatility, leverage, an investment factor, a term premium, a default premium, and a regulatory risk premium. The 10-factor model augments the Carhart four-factor model with the aforementioned six additional factors.

Table 15 summarizes the results from all regressions and robustness tests for each factor. The findings for the market beta (Rm-Rf) and the regulatory premium (REG) are in line with existing literature, thus confirming that the regulatory premium does not affect expected returns and low market betas are mostly attributable to utility stocks, whereas non-utility stocks within the infrastructure sector tend to be more affected by market movements (see Rothballer and Kaserer (2012); Bird, Liem, and Thorp (2012)). Not in line with previous findings are our results regarding SMB, HML, CFVOLA, and INV. We find significant results for SMB but none for HML or INV. CFVOLA is also significant and loads negatively, which is in accordance with the results for stocks in general (see Huang (2009)) but in contrast to Bitsch (2012), who finds that investors value cash flow volatility at a premium. 
Table 15: Summary of results and comparison with existing literature

\begin{tabular}{|c|c|c|c|}
\hline Variables & Hypothesis & Our results & $\begin{array}{l}\text { Comparison with existing } \\
\text { literature }\end{array}$ \\
\hline RM-Rf & $\begin{array}{l}\text { Positive relation between } \\
\text { the market and infrastruc- } \\
\text { ture returns }\end{array}$ & $\begin{array}{l}\text { Significantly positive and } \\
\text { low (i.e., below } 1 \text { ) }\end{array}$ & $\begin{array}{l}\text { In line with the result of } \\
\text { Rothballer and Kaserer } \\
(2012) \text {. Utility stocks have } \\
\text { low market betas whereas } \\
\text { non-utility stocks within the } \\
\text { infrastructure sector have } \\
\text { higher betas. }\end{array}$ \\
\hline SMB & $\begin{array}{l}\text { Negative relation between } \\
\text { size effect and infrastruc- } \\
\text { ture returns. }\end{array}$ & Significantly negative & $\begin{array}{l}\text { Not in line with Bird, Liem, } \\
\text { and Thorp (2012), who find } \\
\text { no significant effect. }\end{array}$ \\
\hline HML & $\begin{array}{l}\text { Positive relation between } \\
\text { value effect and infrastruc- } \\
\text { ture returns. }\end{array}$ & Insignificant & $\begin{array}{l}\text { Not in line with Bird, Liem, } \\
\text { and Thorp (2012), who } \\
\text { find a significantly positive } \\
\text { effect. }\end{array}$ \\
\hline Momentum (MOM) & $\begin{array}{l}\text { Positive relation between } \\
\text { past returns and infrastruc- } \\
\text { ture returns. }\end{array}$ & $\begin{array}{l}\text { (Weakly) significant and } \\
\text { positive }\end{array}$ & $\begin{array}{l}\text { Not yet analyzed in an } \\
\text { infrastructure context. }\end{array}$ \\
\hline $\begin{array}{l}\text { Cash flow volatility } \\
\text { (CFVOLA) }\end{array}$ & $\begin{array}{l}\text { Negative relation between } \\
\text { cash flow volatility and } \\
\text { infrastructure returns. }\end{array}$ & Significantly negative & $\begin{array}{l}\text { In line with Huang (2009), } \\
\text { but not in line with Bitsch } \\
(2012) \text {, who finds a posi- } \\
\text { tive relation between cash } \\
\text { flow volatility and a fund's } \\
\text { value. }\end{array}$ \\
\hline Leverage (LEV) & $\begin{array}{l}\text { Positive relation between } \\
\text { leverage and infrastructure } \\
\text { returns. }\end{array}$ & Significantly positive & $\begin{array}{l}\text { Not yet analyzed in an } \\
\text { infrastructure context. }\end{array}$ \\
\hline Investment growth (INV) & $\begin{array}{l}\text { Positive relation between } \\
\text { investment growth and } \\
\text { infrastructure returns. }\end{array}$ & $\begin{array}{l}\text { Significantly negative re- } \\
\text { lation between INV and } \\
\text { returns of growth companies }\end{array}$ & $\begin{array}{l}\text { Not in line with Chen, } \\
\text { Novy-Marx, and Zhang } \\
(2011) \text {, who find a posi- } \\
\text { tive relation for stocks in } \\
\text { general. }\end{array}$ \\
\hline Term premium (TERM) & $\begin{array}{l}\text { Positive relation between } \\
\text { term structure and infras- } \\
\text { tructure returns. }\end{array}$ & Significantly positive & $\begin{array}{l}\text { Not yet analyzed for infras- } \\
\text { tructure investments but } \\
\text { in line with O'Neal (1998), } \\
\text { who analyzes electric utility } \\
\text { companies. }\end{array}$ \\
\hline Default premium (DEF) & $\begin{array}{l}\text { Positive relation between } \\
\text { default premium and infras- } \\
\text { tructure returns. }\end{array}$ & Significantly positive & $\begin{array}{l}\text { Not yet analyzed for infras- } \\
\text { tructure investments but } \\
\text { in line with O'Neal (1998), } \\
\text { who analyzes electric utility } \\
\text { companies. }\end{array}$ \\
\hline Regulatory premium (REG) & $\begin{array}{l}\text { Positive/negative relation } \\
\text { between regulatory risk and } \\
\text { infrastructure returns. }\end{array}$ & $\begin{array}{l}\text { Positive but overall insignif- } \\
\text { icant }\end{array}$ & $\begin{array}{l}\text { In line with Bird, Liem, and } \\
\text { Thorp (2012), who find no } \\
\text { difference between regulated } \\
\text { and unregulated assets in } \\
\text { the U.S. but a large positive } \\
\text { premium in Australia. }\end{array}$ \\
\hline
\end{tabular}

The findings with respect to MOM, LEV, TERM, and DEF in terms of infrastructure investments have not yet been analyzed in literature. Here we find that infrastructure firms are highly sensitive to 
interest rate changes regarding changes in the term structure. We also find an additional premium for high financial leverage that is economically significant. This emphasizes the need for infrastructure investments to consider leverage as an additional risk factor, since the HML factor alone is not sufficient to capture the return variation with respect to leverage. ${ }^{24}$

Our results are useful for investors and policymakers interested in determining adequate costs of capital, measuring and evaluating infrastructure returns, and understanding the special characteristics of infrastructure investments such as diversification benefits and return volatility. Since factor loadings present the correlation structure between returns and the underlying risk factors, the factor exposures also indicate strategies for minimum variance hedging, for the replication of infrastructure returns, or, in general, for optimizing asset allocation.

Future research might closer investigate the risk exposure of unlisted infrastructure projects. Despite a vast set of significant risk factors in our model, unlisted infrastructure might react differently to our risk factors. Also, it could be very interesting to see how our infrastructure seven- and 10-factor models perform in other countries, specifically with other regulatory regimes. The question of whether cash flow stability in less stable countries leads to expropriation, as indicated by Sawant (2010), is still unanswered. Similarly, political risk factors (i.e., corruption, risk of expropriation) and their effect on infrastructure returns could be analyzed.

\section{Appendix A Commercial Infrastructure Indices}

We apply the infrastructure 10-factor model to widely used commercial infrastructure indices (see Table A). Columns 1-5 refer to U.S.-specific infrastructure indices provided by UBS, FTSE/Macquarie, and Dow Jones Brookfield (DJB). Columns 6 and 7 include indices on developed countries and countries worldwide, respectively. The highest explanatory power is observed for the DJB Americas infrastructure index with an adjusted R-square of $73 \%$.

\footnotetext{
${ }^{24}$ Furthermore, we showed that infrastructure investments, in general, neither offer an inflation hedge, nor are able to protect against downside risk. Only for small utility firms an inflation hedge can be documented which confirms results for other countries and time periods (see Rödel and Rothballer (2012); Bird, Liem, and Thorp (2012)).
} 
Table A: Regression on commercial infrastructure indices using infrastructure 10-factor model

\begin{tabular}{|c|c|c|c|c|c|c|c|}
\hline & (1) & $(2)$ & (3) & (4) & (5) & (6) & (7) \\
\hline Variables & $\begin{array}{l}\text { UBS infra- } \\
\text { stucture } \\
\text { and utilities } \\
\text { (USA) }\end{array}$ & $\begin{array}{l}\text { UBS infra- } \\
\text { structure } \\
\text { (USA) }\end{array}$ & $\begin{array}{l}\text { FTSE Mac- } \\
\text { quarie North } \\
\text { America }\end{array}$ & $\begin{array}{l}\text { UBS utilities } \\
\text { (USA) }\end{array}$ & $\begin{array}{l}\text { Dow Jones } \\
\text { Brookfield } \\
\text { Americas } \\
\text { infrastructure }\end{array}$ & $\begin{array}{l}\text { UBS infras- } \\
\text { tructure } \\
\text { and utilities } \\
\text { (developed } \\
\text { countries) }\end{array}$ & $\begin{array}{l}\text { UBS } 50-50 \\
\text { infrastructure } \\
\text { and utilities } \\
\text { (global) }\end{array}$ \\
\hline$\beta_{M}$ & $\begin{array}{l}0.616^{* * *} \\
(0.0505)\end{array}$ & $\begin{array}{l}1.617^{* * *} \\
(0.262)\end{array}$ & $\begin{array}{l}0.871^{* * *} \\
(0.0957)\end{array}$ & $\begin{array}{l}0.611^{* * *} \\
(0.0506)\end{array}$ & $\begin{array}{l}0.818^{* * *} \\
(0.0681)\end{array}$ & $\begin{array}{l}0.559 * * * \\
(0.0480)\end{array}$ & $\begin{array}{l}0.534 * * * \\
(0.0550)\end{array}$ \\
\hline$\beta_{S M B}$ & $\begin{array}{l}-0.153^{* *} \\
(0.0620)\end{array}$ & $\begin{array}{l}0.562^{*} \\
(0.313)\end{array}$ & $\begin{array}{l}-0.464^{* * *} \\
(0.126)\end{array}$ & $\begin{array}{l}-0.158^{* *} \\
(0.0621)\end{array}$ & $\begin{array}{l}-0.116 \\
(0.0941)\end{array}$ & $\begin{array}{l}-0.160^{* * *} \\
(0.0583)\end{array}$ & $\begin{array}{l}-0.0379 \\
(0.0649)\end{array}$ \\
\hline$\beta_{H M L}$ & $\begin{array}{l}0.214^{* * *} \\
(0.0680)\end{array}$ & $\begin{array}{l}-1.116^{* * *} \\
(0.336)\end{array}$ & $\begin{array}{l}0.0348 \\
(0.132)\end{array}$ & $\begin{array}{l}0.219^{* * *} \\
(0.0682)\end{array}$ & $\begin{array}{l}-0.171^{*} \\
(0.0983)\end{array}$ & $\begin{array}{l}0.228 * * * \\
(0.0641)\end{array}$ & $\begin{array}{l}0.232^{* * *} \\
(0.0725)\end{array}$ \\
\hline$\beta_{M O M}$ & $\begin{array}{l}0.0811^{* *} \\
(0.0382)\end{array}$ & $\begin{array}{l}-0.131 \\
(0.177)\end{array}$ & $\begin{array}{l}0.112^{*} \\
(0.0577)\end{array}$ & $\begin{array}{l}0.0846^{* *} \\
(0.0383)\end{array}$ & $\begin{array}{l}0.100 * * \\
(0.0429)\end{array}$ & $\begin{array}{l}0.0984 * * * \\
(0.0360)\end{array}$ & $\begin{array}{l}0.00918 \\
(0.0392)\end{array}$ \\
\hline$\beta_{C F V O L A}$ & $\begin{array}{l}-0.318^{* * * *} \\
(0.0913)\end{array}$ & $\begin{array}{l}-0.460 \\
(0.446)\end{array}$ & $\begin{array}{l}0.00154 \\
(0.155)\end{array}$ & $\begin{array}{l}-0.323^{* * *} \\
(0.0916)\end{array}$ & $\begin{array}{l}-0.0315 \\
(0.108)\end{array}$ & $\begin{array}{l}-0.0369 \\
(0.0859)\end{array}$ & $\begin{array}{l}0.0846 \\
(0.0956)\end{array}$ \\
\hline$\beta_{L E V}$ & $\begin{array}{l}0.476^{* * * *} \\
(0.0687)\end{array}$ & $\begin{array}{l}0.306 \\
(0.338)\end{array}$ & $\begin{array}{l}0.380^{* * *} \\
(0.124)\end{array}$ & $\begin{array}{l}0.485^{* * *} \\
(0.0688)\end{array}$ & $\begin{array}{l}0.375^{* * *} \\
(0.0814)\end{array}$ & $\begin{array}{l}0.256^{* * *} \\
(0.0646)\end{array}$ & $\begin{array}{l}0.149 * * \\
(0.0716)\end{array}$ \\
\hline$\beta_{I N V}$ & $\begin{array}{l}-0.0697 \\
(0.0767)\end{array}$ & $\begin{array}{l}-0.223 \\
(0.379)\end{array}$ & $\begin{array}{l}-0.143 \\
(0.128)\end{array}$ & $\begin{array}{l}-0.0685 \\
(0.0769)\end{array}$ & $\begin{array}{l}-0.107 \\
(0.0943)\end{array}$ & $\begin{array}{l}-0.104 \\
(0.0722)\end{array}$ & $\begin{array}{c}-0.194^{* *} \\
(0.0819)\end{array}$ \\
\hline$\beta_{T E R M}$ & $\begin{array}{l}0.192^{* * *} \\
(0.0636)\end{array}$ & $\begin{array}{c}-0.554^{*} \\
(0.299)\end{array}$ & $\begin{array}{l}0.0767 \\
(0.0847)\end{array}$ & $\begin{array}{l}0.199 * * * \\
(0.0638)\end{array}$ & $\begin{array}{l}0.0372 \\
(0.0603)\end{array}$ & $\begin{array}{l}0.251^{* * *} \\
(0.0598)\end{array}$ & $\begin{array}{l}0.230 * * * \\
(0.0646)\end{array}$ \\
\hline$\beta_{D E F}$ & $\begin{array}{l}0.327^{* * *} \\
(0.118)\end{array}$ & $\begin{array}{c}-0.987^{*} \\
(0.530)\end{array}$ & $\begin{array}{l}0.0671 \\
(0.140)\end{array}$ & $\begin{array}{l}0.337^{* * *} \\
(0.118)\end{array}$ & $\begin{array}{l}0.0859 \\
(0.106)\end{array}$ & $\begin{array}{l}0.449^{* * *} \\
(0.111)\end{array}$ & $\begin{array}{l}0.433^{* * *} \\
(0.120)\end{array}$ \\
\hline$\beta_{R E G}$ & $\begin{array}{l}0.169 \\
(0.314)\end{array}$ & $\begin{array}{l}3.248^{* *} \\
(1.438)\end{array}$ & $\begin{array}{l}1.700^{* *} \\
(0.721)\end{array}$ & $\begin{array}{l}0.136 \\
(0.314)\end{array}$ & $\begin{array}{l}0.768 \\
(0.499)\end{array}$ & $\begin{array}{l}0.0224 \\
(0.296)\end{array}$ & $\begin{array}{l}-0.284 \\
(0.325)\end{array}$ \\
\hline$\alpha$ & $\begin{array}{l}0.166 \\
(0.187)\end{array}$ & $\begin{array}{l}1.535 \\
(1.014)\end{array}$ & $\begin{array}{l}0.0342 \\
(0.282)\end{array}$ & $\begin{array}{l}0.159 \\
(0.187)\end{array}$ & $\begin{array}{l}0.443^{* *} \\
(0.212)\end{array}$ & $\begin{array}{l}0.142 \\
(0.176)\end{array}$ & $\begin{array}{l}0.110 \\
(0.209)\end{array}$ \\
\hline $\begin{array}{l}\text { Monthly obs. } \\
\text { Adj. } R^{2}\end{array}$ & $\begin{array}{l}264 \\
52.8 \%\end{array}$ & $\begin{array}{l}161 \\
37.4 \%\end{array}$ & $\begin{array}{l}96 \\
64.8 \%\end{array}$ & $\begin{array}{l}264 \\
52.8 \%\end{array}$ & $\begin{array}{l}108 \\
73.0 \%\end{array}$ & $\begin{array}{l}264 \\
52.0 \%\end{array}$ & $\begin{array}{l}203 \\
54.3 \%\end{array}$ \\
\hline
\end{tabular}

The lowest explanatory power is observed for the UBS Infrastructure Index (Column 2 of Table A). However, the relatively small degree of explanation is not surprising given the composition of that particular index, which does not meet our definition of infrastructure and does not include any utility companies but refers to concessions, leases, and freehold of transportation and communication services. Most important to note is that the exposure of the UBS Infrastructure Index (Column 2) to market risk is about twice as large as for the infrastructure indices. This is similar to the results in Table 10 regarding the analysis of subsectors. Although market exposure is much larger in this case, we again conclude that utility stocks are the main driver for decreasing market exposure. Our model performs surprisingly well both in developed countries and globally, even though our constructed factors are solely based on the U.S. infrastructure market. However, this result is only fractionally based on co-integrated markets and more the outcome of the composition of the indices, which are both outweighed by the U.S. market. 


\section{Appendix B GJR-GARCH and Fat Tails}

Main results in the previous sections are presented without GJR-GARCH (Glosten, Jagannathan, and Runkle (1993)) because heteroscedasticity and non-linearities are taken into consideration by NeweyWest (1987) error correction. However, in the spirit of Bird, Liem, and Thorp (2012), we also run a GJR-GARCH (Glosten, Jagannathan, and Runkle (1993)) model to simulate the asymmetric volatility structure of infrastructure returns on the indices they used with respect to the U.S. market. ${ }^{25}$ The mean equation is identical to Equation (4) in Section 2 and errors of the mean equation are t-distributed. The variance equation assumes the form $h_{i, t}=\gamma_{0}+\gamma_{1} \epsilon_{i, t-1}^{2}+\gamma_{2} h_{i, t-1}+\gamma_{3} \epsilon_{i, t-1}^{2} I_{t-1}$, where all variables are identically defined as in Bird, Liem, and Thorp (2012). We run the infrastructure 10-factor factor model against all commercial indices with respect to the U.S. market. These indices are also used by Bird, Liem, and Thorp (2012); hence this should guarantee the comparability of our estimation results to their findings. See Table B for the results. All three indices show significant ARCH $\left(\gamma_{1}\right)$ and GARCH $\left(\gamma_{2}\right)$ effects, but no significant $\gamma_{3}$-loadings (also known as leverage effect) in Indexes (1) and (3). In contrast to Bird, Liem, and Thorp (2012), we again find a significant and negative size impact for both Indexes (1) and (3) but no effect in Index (2). Interestingly, there is a positive impact on the term and default premium regarding Indexes (1) and (3) but a negative one on term and default risk for Index (2), suggesting that this index offers a potential hedge against changes in the slope of the yield curve and against times of increasing default risk.

Most importantly, we confirm a highly significant and economically relevant impact of regulatory risk on Index (2). The average risk premium amounts to $1 \%$ p.a. and can be interpreted as a compensation for investors who experience a capped rate of return in the infrastructure sector. This result is surprising given that the factor is constructed as the spread between bond returns of utility and industrial companies. The UBS Infrastructure Index, however, includes neither utilities nor industrial companies, which corroborates that our factor is a good approximation for capturing regulatory risk in the infrastructure sector. Taking the explanatory power of our model into consideration, we see that the adjusted R-square substantially improves for the UBS Infrastructure and Utilities Index to $50.2 \%$ compared to the $37.3 \%$ for the Fama/French three-factor model. Similarly, the UBS Utilities Index increases from $37.1 \%$ to $50.1 \%$ in our model. In contrast, the R-square for the UBS Infrastructure Index does not increase through our model because of the aforementioned definition of that particular index. Overall, our factors improve the

\footnotetext{
${ }^{25}$ That is, the (1) UBS Utilities and Infrastructure Index, (2) UBS Infrastructure Index, and (3) UBS Utilities Index.
} 


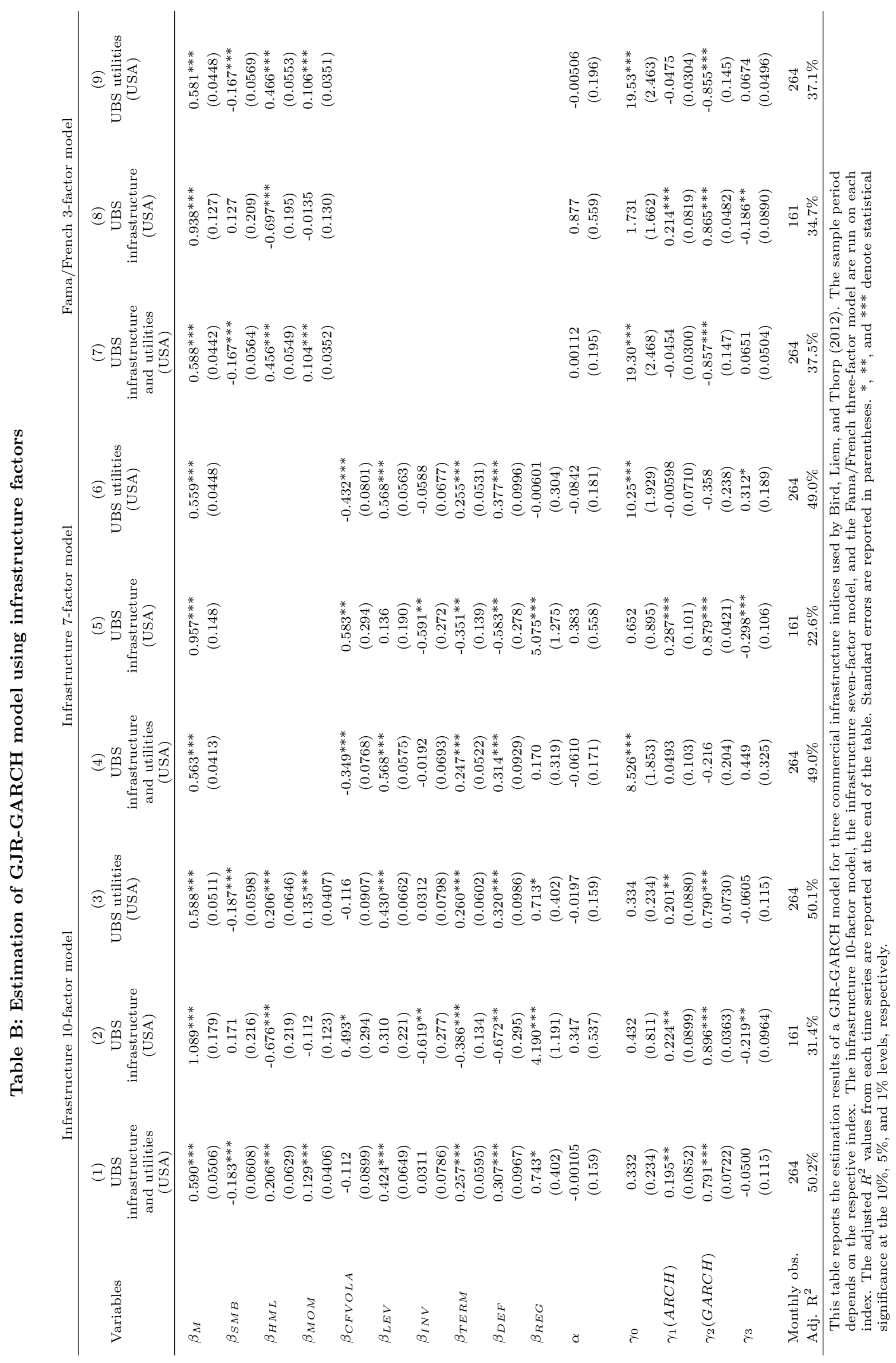


predictive power for infrastructure returns.

\section{Appendix C Stepwise Inclusion of Variables}

To justify the number of factors and to illustrate their significance, we also stepwisely include each infrastructure-specific factor in the model. Table $\mathrm{C}$ shows that the infrastructure-specific variables are consistently significant as in the previous regression tables in this paper. Only the investment factor (INV) is not significant which is also consistent with the previous regression results in this paper.

Table C: Stepwise regression

\begin{tabular}{|c|c|c|c|c|c|c|c|}
\hline Variables & $\begin{array}{l}(1) \\
\text { Model } 1\end{array}$ & $\begin{array}{l}(2) \\
\text { Model } 2\end{array}$ & $\begin{array}{l}(3) \\
\text { Model } 3\end{array}$ & $\begin{array}{l}(4) \\
\text { Model } 4\end{array}$ & $\begin{array}{l}5) \\
\text { Model } 5\end{array}$ & $\begin{array}{l}(6) \\
\text { Model } 6\end{array}$ & $\begin{array}{l}(7) \\
\text { Model } 7\end{array}$ \\
\hline$\beta_{M}$ & $\begin{array}{l}0.775 * * * \\
(0.0290)\end{array}$ & $\begin{array}{l}0.786 * * * \\
(0.0281)\end{array}$ & $\begin{array}{l}0.774^{* * *} \\
(0.0292)\end{array}$ & $\begin{array}{l}0.722^{* * *} \\
(0.0276)\end{array}$ & $\begin{array}{l}0.722 * * * \\
(0.0277)\end{array}$ & $\begin{array}{l}0.721 * * * \\
(0.0269)\end{array}$ & $\begin{array}{l}0.725^{* * *} \\
(0.0274)\end{array}$ \\
\hline$\beta_{S M B}$ & $\begin{array}{l}-0.181 * * * \\
(0.0398)\end{array}$ & $\begin{array}{l}-0.151^{* * *} \\
(0.0413)\end{array}$ & $\begin{array}{l}-0.129^{* * *} \\
(0.0414)\end{array}$ & $\begin{array}{l}-0.150^{* * *} \\
(0.0415)\end{array}$ & $\begin{array}{l}-0.151^{* * *} \\
(0.0417)\end{array}$ & $\begin{array}{l}-0.136^{* * *} \\
(0.0435)\end{array}$ & $\begin{array}{l}-0.146^{* * *} \\
(0.0452)\end{array}$ \\
\hline$\beta_{H M L}$ & $\begin{array}{l}0.0361 \\
(0.0471)\end{array}$ & $\begin{array}{l}0.0291 \\
(0.0448)\end{array}$ & $\begin{array}{l}0.0505 \\
(0.0502)\end{array}$ & $\begin{array}{l}0.0192 \\
(0.0474)\end{array}$ & $\begin{array}{l}0.0203 \\
(0.0481)\end{array}$ & $\begin{array}{l}0.0336 \\
(0.0493)\end{array}$ & $\begin{array}{l}0.0495 \\
(0.0467)\end{array}$ \\
\hline$\beta_{M O M}$ & & & & & & & $\begin{array}{l}0.0517^{*} \\
(0.0305)\end{array}$ \\
\hline$\beta_{L E V}$ & $\begin{array}{l}0.196^{* * *} \\
(0.0545)\end{array}$ & $\begin{array}{l}0.224^{* * *} \\
(0.0530)\end{array}$ & $\begin{array}{l}0.183^{* * *} \\
(0.0619)\end{array}$ & $\begin{array}{l}0.185^{* * *} \\
(0.0542)\end{array}$ & $\begin{array}{l}0.186^{* * *} \\
(0.0534)\end{array}$ & $\begin{array}{l}0.172^{* * *} \\
(0.0520)\end{array}$ & $\begin{array}{l}0.168^{* * *} \\
(0.0525)\end{array}$ \\
\hline$\beta_{C F V O L A}$ & & $\begin{array}{l}-0.149 * * * \\
(0.0563)\end{array}$ & $\begin{array}{l}-0.129^{* *} \\
(0.0555)\end{array}$ & $\begin{array}{l}-0.160 * * * \\
(0.0496)\end{array}$ & $\begin{array}{l}-0.155^{* * *} \\
(0.0494)\end{array}$ & $\begin{array}{l}-0.155^{* * *} \\
(0.0482)\end{array}$ & $\begin{array}{l}-0.138 * * * \\
(0.0496)\end{array}$ \\
\hline$\beta_{T E R M}$ & & & $\begin{array}{l}0.115^{* * *} \\
(0.0390)\end{array}$ & $\begin{array}{l}0.198 * * * \\
(0.0439)\end{array}$ & $\begin{array}{l}0.194 * * * \\
(0.0441)\end{array}$ & $\begin{array}{l}0.170 * * * \\
(0.0439)\end{array}$ & $\begin{array}{l}0.173^{* * *} \\
(0.0446)\end{array}$ \\
\hline$\beta_{D E F}$ & & & & $\begin{array}{l}0.282^{* * *} \\
(0.0739)\end{array}$ & $\begin{array}{l}0.270 * * * \\
(0.0704)\end{array}$ & $\begin{array}{l}0.239 * * * \\
(0.0694)\end{array}$ & $\begin{array}{l}0.267 * * * \\
(0.0737)\end{array}$ \\
\hline$\beta_{I N V}$ & & & & & $\begin{array}{l}-0.0643 \\
(0.0585)\end{array}$ & $\begin{array}{l}-0.0517 \\
(0.0570)\end{array}$ & $\begin{array}{l}-0.0615 \\
(0.0566)\end{array}$ \\
\hline$\beta_{R E G}$ & & & & & & $\begin{array}{l}0.322^{*} \\
(0.174)\end{array}$ & $\begin{array}{l}0.328^{*} \\
(0.170)\end{array}$ \\
\hline$\alpha$ & $\begin{array}{l}0.0187 \\
(0.112)\end{array}$ & $\begin{array}{l}0.0164 \\
(0.110)\end{array}$ & $\begin{array}{c}-0.0229 \\
(0.108)\end{array}$ & $\begin{array}{c}-0.0192 \\
(0.103)\end{array}$ & $\begin{array}{l}-0.00848 \\
(0.101)\end{array}$ & $\begin{array}{r}-0.00860 \\
(0.0999)\end{array}$ & $\begin{array}{c}-0.0486 \\
(0.103)\end{array}$ \\
\hline $\begin{array}{l}\text { Monthly obs. } \\
\text { Adj. } R^{2}\end{array}$ & $\begin{array}{l}384 \\
71.6 \%\end{array}$ & $\begin{array}{l}384 \\
72.2 \%\end{array}$ & $\begin{array}{l}384 \\
73.3 \%\end{array}$ & $\begin{array}{l}384 \\
74.5 \%\end{array}$ & $\begin{array}{l}384 \\
74.5 \%\end{array}$ & $\begin{array}{l}384 \\
74.7 \%\end{array}$ & $\begin{array}{l}384 \\
75.0 \%\end{array}$ \\
\hline
\end{tabular}

This table reports regression results for different model specifications where independent variables are added stepwisely. The sample period is January 1980 to December 2011. The adjusted $R^{2}$ values from each time series are reported at the end of the table. Standard errors are reported in parentheses and are computed using the Newey-West (1987) correction for heteroscedasticity and serial correlation. $*$, **, and $* * *$ denote statistical significance at the $10 \%, 5 \%$, and $1 \%$ levels, respectively. 


\section{Literature}

Ammann, M., Odoni, S. and Oesch, D., 'An alternative three-factor model for international markets: Evidence from the European monetary union', Journal of Banking and Finance, Vol. 36, 2012, pp. $1857-1864$.

Ang, A., Hodrick R. J., Xing Y. and Zhang X., 'The cross-section of volatility and expected returns', Journal of Finance, Vol. 61, 2006, pp. 259-299.

Ang, A., Bekaert, G. and Wei, M. I. N., 'The term structure of real rates and expected inflation', Journal of Finance, Vol. 63, 2008, pp. 797-849.

Ang, A., Liu, J. and Schwarz, K., 'Using stocks or portfolios in tests of factor models', Working Paper (University of Columbia, 2010).

Bauman, W. S., Conover, C. M. and Miller, R. E., 'Growth versus value and large-cap versus small-cap stocks in international markets', Financial Analysts Journal, Vol. 54, 1998, pp. 75-89.

Baur, R., Hlavinek, P., Kukharchyk, T., Marsalek, J. and Mahrikova, I., 'Aging and renewal of urban water infrastructure integrated urban water resources management', Springer Netherlands, 2006.

Beecher, J.A. and Kalmbach, J.A., 'Structure, regulation, and pricing of water in the United States: A study of the great lakes region', Utilities Policy, Vol. 24, 2013, pp. 32-47.

Bhandari, L. C., 'Debt/equity ratio and expected common stock returns: Empirical evidence', Journal of Finance, Vol. 43, 1988, pp. 507-528.

Bird, R., Liem H. and Thorp, S., 'Infrastructure: Real assets and real returns', European Financial Management, 2012, doi: 10.1111/j.1468-036X.2012.00650.x.

Bitsch, F., 'Do investors value cash flow stability of listed infrastructure funds?', Working Paper (TU Munich, 2012).

Bitsch, F., Buchner, A. and Kaserer, C., 'Risk, return and cash flow characteristics of infrastructure fund investments', EIB papers, Vol. 15, 2010, pp. 106-136. 
Bradley, M., Jarrell, G. A. and Han Kim, E., 'On the existence of an optimal capital structure: Theory and evidence', Journal of Finance, Vol. 39, 1984, pp. 857-878.

Campbell, J. Y., Lo, A.W. and MacKinlay, C., 'The econometrics of financial markets', Princeton University Press, New Jersey, 1997.

Carhart, M. M., 'On persistence in mutual fund performance', Journal of Finance, Vol. 52, 1997, pp. $57-82$.

Chen, L., Novy-Marx, R. and Zhang, L., 'An alternative three-factor model', Working Paper (Washington University in St. Louis, 2011).

Chou, P. H., Ho, P. H. and Ko, K. C., 'Do industries matter in explaining stock returns and asset-pricing anomalies?', Journal of Banking and Finance, Vol. 36, 2012, pp. 355-370.

Cochrane, J.H., 'Asset pricing', Princeton University Press, New Jersey, 2005.

Daniel, K. and Titman S., 'Evidence on the characteristics of cross sectional variation in stock returns', Journal of Finance, Vol. 52, 1997, pp. 1-33.

Dechant, T. and Finkenzeller, K., 'The role of infrastructure investments in a multi-asset portfolio Answers from dynamic asset allocation', Working Paper (University of Regensburg, 2012).

Fama, E. F. and French, K. R., 'Business conditions and expected returns on stocks and bonds', Journal of Financial Economics, Vol. 25, 1989, pp. 23-49.

Fama, E. F. and French, K.R., 'The cross-section of expected stock returns', Journal of Finance, Vol. 47, 1992, pp. 427-465.

Fama, E. F. and French, K. R., 'Common risk factors in the returns on stocks and bonds', Journal of Financial Economics, Vol. 33, 1993, pp. 3-56.

Fama, E. F. and French, K. R., 'Industry costs of equity', Journal of Financial Economics, Vol. 43, 1997, pp. 153-193.

Fama, E. F. and MacBeth, J. D., 'Risk, return, and equilibrium: empirical tests', Journal of Political Economy, Vol. 81, 1973, pp. 607-636. 
Finkenzeller, K., Dechant, T. and Schäfers, W., 'Infrastructure: A new dimension of real estate? An asset allocation analysis', Journal of Property Investment and Finance, Vol. 28, 2010, pp. 263-274.

Gibbons, M. R., Ross, S. A. and Shanken, J., 'A test of the efficiency of a given portfolio', Econometrica, Vol. 57, 1989, pp. 1121-1152.

Glosten, L. R., Jagannathan, R. and Runkle, D. E., 'On the relation between the expected value and the volatility of the nominal excess returns on stocks', Journal of Finance, Vol. 48, 1993, pp. 1779-1801.

Gregory, A. and Michou, M., 'Industry Cost of Equity Capital: UK Evidence', Journal of Business Finance \& Accounting, Vol. 36, 2009, pp. 679-704.

Huang, A. G., 'The cross section of cashflow volatility and expected stock returns', Journal of Empirical Finance, Vol. 16, 2009, pp. 409-429.

Jagannathan, R. and Wang, Z., 'The conditional CAPM and the cross-section of expected returns', Journal of Finance, Vol. 51, 1996, pp. 3-53.

Jegadeesh, N. and Titman, S., 'Returns to buying winners and selling losers: Implications for stock market efficiency', Journal of Finance, Vol. 48, 1993, pp. 65-91.

Kessides, I. N., 'Reforming infrastructure: Privatization, regulation, and competition', World Bank, 2004.

Lintner, J., 'The valuation of risk assets and the selection of risky investments in stock portfolios and capital budgets', Review of Economics and Statistics, Vol. 47, 1965, pp. 13-37.

Minton, B. A. and Schrand, C., 'The impact of cash flow volatility on discretionary investment and the costs of debt and equity financing', Journal of Financial Economics, Vol. 54, 1999, pp. $423-460$.

Mohanty, S. K. and Nandha, M., 'Oil risk exposure: The case of the US oil and gas sector', Financial Review, Vol. 46, 2011, pp. 165-191.

Mossin, J., 'Equilibrium in a capital asset market', Econometrica, Vol. 34, 1966, pp. 768-783.

Newbery, D. M., 'Privatization, restructuring, and regulation of network utilities', MIT Press, 2002. 
Newell, G. and Peng, H., 'The role of U.S. Infrastructure in investment portfolios', Journal of Real Estate Portfolio Management, Vol. 14, 2008, pp. 21-34.

Newey, W. K. and West, K. D., 'A simple, positive semi-definite, heteroskedasticity and autocorrelation consistent covariance matrix', Econometrica, Vol. 55, 1987, pp. 703-708.

O'Neal, E. S., 'Why electric utility stocks are sensitive to interest rates', Financial Review, Vol. 33, 1998, pp. $147-162$.

Peterson, J. D. and Hsieh, C. H., 'Do common risk factors in the returns on stocks and bonds explain returns on REITS?', Real Estate Economics, Vol. 25, 1997, pp. 321-345.

Rödel, M. and Rothballer, C., 'Infrastructure as hedge against inflation - Fact or fantasy?', Journal of Alternative Investments, Vol. 15, 2012, pp. 110-123.

Rothballer, C. and Kaserer, C., 'The risk profile of infrastructure investments: Challenging conventional wisdom', Journal of Structured Finance, Vol. 18, 2012, pp. 95-109.

Rountree, B., Weston J. P. and Allayannis, G., 'Do investors value smooth performance?', Journal of Financial Economics, Vol. 90, 2008, pp. 237-251.

Sadorsky, P., 'Risk factors in stock returns of Canadian oil and gas companies', Energy Economics, Vol. 23, 2001, pp. 17-28.

Sawant, R. J., 'The economics of large-scale infrastructure FDI: The case of project finance', Journal of International Business Studies, Vol. 41, 2010, pp. 1036-1055.

Shanken, J., 'On the estimation of beta-pricing models', Review of Financial Studies, Vol. 5, 1992, pp. $1-55$.

Sharpe, W. F., 'Capital asset prices: A theory of market equilibrium under conditions of risk', Journal of Finance, Vol. 19, 1964, pp. 425-442.

Sweeney, R. J. and Warga, A. D., 'The pricing of interest-rate risk: Evidence from the stock market', Journal of Finance, Vol. 41, 1986, pp. 393-410.

Treynor, J. and Mazuy, K., 'Can mutual funds outguess the market', Harvard Business Review, Vol. 44, 1966, pp. 131-136. 
Vassalou, M., 'News related to future GDP growth as a risk factor in equity returns', Journal of Financial Economics, Vol. 68, 2003, pp. 47-73.

Viale, A. M., Kolari, J. W. and Fraser D. R., 'Common risk factors in bank stocks', Journal of Banking and Finance, Vol. 33, 2009, pp. 464-472. 